\title{
Modeling reactive ammonia uptake by secondary organic aerosol in CMAQ: application to the continental US
}

\author{
Shupeng Zhu ${ }^{1}$, Jeremy R. Horne ${ }^{1}$, Julia Montoya-Aguilera ${ }^{2}$, Mallory L. Hinks ${ }^{2}$, Sergey A. Nizkorodov ${ }^{2}$, and \\ Donald Dabdub $^{1}$ \\ ${ }^{1}$ Computational Environmental Sciences Laboratory, Department of Mechanical and Aerospace Engineering, \\ University of California, Irvine, Irvine, CA, 92697-3975, USA \\ ${ }^{2}$ Department of Chemistry, University of California, Irvine, Irvine, CA, 92697-3975, USA
}

Correspondence: Donald Dabdub (ddabdub@uci.edu)

Received: 12 October 2017 - Discussion started: 6 November 2017

Revised: 1 February 2018 - Accepted: 1 February 2018 - Published: 13 March 2018

\begin{abstract}
Ammonium salts such as ammonium nitrate and ammonium sulfate constitute an important fraction of the total fine particulate matter $\left(\mathrm{PM}_{2.5}\right)$ mass. While the conversion of inorganic gases into particulate-phase sulfate, nitrate, and ammonium is now well understood, there is considerable uncertainty over interactions between gas-phase ammonia and secondary organic aerosols (SOAs). Observations have confirmed that ammonia can react with carbonyl compounds in SOA, forming nitrogen-containing organic compounds (NOCs). This chemistry consumes gas-phase $\mathrm{NH}_{3}$ and may therefore affect the amount of ammonium nitrate and ammonium sulfate in particulate matter (PM) as well as particle acidity. In order to investigate the importance of such reactions, a first-order loss rate for ammonia onto SOA was implemented into the Community Multiscale Air Quality (CMAQ) model based on the ammonia uptake coefficients reported in the literature. Simulations over the continental US were performed for the winter and summer of 2011 with a range of uptake coefficients $\left(10^{-3}-10^{-5}\right)$. Simulation results indicate that a significant reduction in gas-phase ammonia may be possible due to its uptake onto SOA; domainaveraged ammonia concentrations decrease by $31.3 \%$ in the winter and $67.0 \%$ in the summer with the highest uptake coefficient $\left(10^{-3}\right)$. As a result, the concentration of particulate matter is also significantly affected, with a distinct spatial pattern over different seasons. PM concentrations decreased during the winter, largely due to the reduction in ammonium nitrate concentrations. On the other hand, PM concentrations increased during the summer due to increased biogenic SOA (BIOSOA) production resulting from enhanced acid-
\end{abstract}

catalyzed uptake of isoprene-derived epoxides. Since ammonia emissions are expected to increase in the future, it is important to include $\mathrm{NH}_{3}+$ SOA chemistry in air quality models.

\section{Introduction}

As the most abundant basic gas in the atmosphere (Behera et al., 2013), gaseous ammonia $\left(\mathrm{NH}_{3}\right)$ has long been considered responsible for controlling the eutrophication and acidification of ecosystems (Sutton et al., 1993; Erisman et al., 2008; Sheppard et al., 2011). More recently, studies also demonstrated the importance of ammonia in the formation of airborne fine particulate matter $\left(\mathrm{PM}_{2.5}\right)$ (West et al., 1999; Vayenas et al., 2005; Wang et al., 2013). Through reactions with acidic species, ammonia is converted into ammonium salts, such as ammonium nitrate and ammonium sulfate, which constitute an important fraction of total $\mathrm{PM}_{2.5}$ mass (Behera and Sharma, 2010). These aerosols have been proven to affect human health (Pope III et al., 2002; Lelieveld et al., 2015), visibility (Ye et al., 2011), and the atmospheric radiative balance (Xu and Penner, 2012; Park et al., 2014). In the US, the largest ammonia emission source is agricultural activity ( $\sim 85 \%$ of total US ammonia emissions) (Pinder et al., 2004, 2006), largely from animal waste and commercial fertilizer application, such as the intensive farming in California's Central Valley (Jovan and McCune, 2005) and industrialized hog farms in central North Carolina (McCulloch et al., 1998; Aneja et al., 2000). The ammonia-rich 
plumes from those areas drive most of the nitric acid into the particle phase, resulting in high $\mathrm{PM}_{2.5}$ concentrations in those regions (Neuman et al., 2003; Baek and Aneja, 2004). Recent studies have also shown that atmospheric ammonia has increased during the last two decades, a trend that is expected to continue as a result of global warming, increasing agricultural activity and intensifying fertilizer use due to a growing population (Galloway et al., 2008; Amann et al., 2013; Warner et al., 2017).

While the conversion of inorganic gases into particulatephase sulfate, nitrate, and ammonium is now fairly well understood (Seinfeld and Pandis, 2016), there is considerable uncertainty over interactions between gas-phase ammonia and organic compounds in secondary organic aerosols (SOAs). Laboratory studies have shown that ammonia can react with SOA compounds in two ways. It can either react with organic acids to form ammonium salts $(\mathrm{Na}$ et al., 2007) or participate in reactions with certain carbonyl compounds forming heterocyclic nitrogen-containing organic compounds (NOCs) (Updyke et al., 2012; Laskin et al., 2015). In addition, a browning effect on SOA under $\mathrm{NH}_{3}$ exposure is observed by Updyke et al. (2012), indicating the production of light-absorbing products. These processes are not included in current air quality models, which could lead to overestimation of gaseous ammonia concentrations and thus inorganic aerosol concentration. Additionally, the neglect of these two processes may also result in underestimation of organics aerosol, especially species related to acid-catalyzed reactions (Lin et al., 2013), and in incorrect prediction of aerosol particle acidity.

Recently, chemical uptake coefficients for ammonia onto SOA were reported for the first time by Liu et al. (2015). Those coefficients were on the order of $\sim 10^{-3}-10^{-2}$ for fresh SOA, decreasing significantly to $<10^{-5}$ after $6 \mathrm{~h}$ of reaction. They observed that the NOC mass contributed $8.9 \pm 1.7$ and $31.5 \pm 4.4 \mathrm{wt} \%$ to the total $\alpha$-pinene and $m$ xylene-derived SOA, respectively, and $4-15 \mathrm{wt} \%$ of the total nitrogen in the system. If such large fraction of SOA compounds can be converted to NOCs it can have large effect on both $\mathrm{NH}_{3}$ and $\mathrm{PM}$ concentrations.

In this work, we investigate the impact of ammonia uptake by $\mathrm{SOA}$ on $\mathrm{PM}_{2.5}$ and $\mathrm{NH}_{3}$ concentrations, by implementing a first-order loss rate for ammonia onto SOA into the Community Multiscale Air Quality (CMAQ) modeling system based on ammonia uptake coefficients reported by Liu et al. (2015). Air quality simulations over the continental US were performed with a range of uptake coefficients to determine the sensitivity of $\mathrm{PM}_{2.5}$ and $\mathrm{NH}_{3}$ concentration to the magnitude of the uptake coefficient. Furthermore, in order to investigate the seasonal impact on this process, simulations were conducted for both winter and summer. The modeling method used in this analysis will first be presented in Sect. 2 . Then, simulation results will be analyzed based on both observational data and sensitivity comparisons between differ- ent scenarios in Sect. 3. Finally, in Sect. 4, the importance of including this process in air quality models will be discussed.

\section{Methodology}

The CMAQ modeling system (Byun and Schere, 2006) is a widely used state-of-the-art chemical transport model. In the United States, it is among the most commonly used air quality models in attainment demonstrations for National Ambient Air Quality Standards for ozone and $\mathrm{PM}_{2.5}$ (US EPA, 2007). In this study, eight simulations were conducted using the latest 2017 release of CMAQ (version 5.2), including one base case simulation for the winter (Jan. 1 - Feb. 27, 2011), one base case simulation for the summer (1 July-30 August 2011), and three different $\mathrm{NH}_{3}$ uptake scenarios for each period. The carbon bond version 6 (CB6) mechanism (Yarwood et al., 2010) was used for the gas-phase chemistry, which includes 127 species as detailed on the website (Adams, 2017), and the AERO6 module was used for aerosol dynamics, which includes 21 inorganic species and 34 organic species (28 SOA and 6 primary organic species) as detailed on the CMASWIKI website (Pye, 2016). The modeling domain used in this study covers the contiguous US using a $12 \mathrm{~km} \times 12 \mathrm{~km}$ horizontal-grid resolution (resulting in $396(x) \times 246(y)=97416$ grid cells) and a 29-layer logarithmic vertical structure (set on a terrain following sigma coordinate, from the surface to $50 \mathrm{hPa}$ ) with the depth of the first layer around $26 \mathrm{~m}$. Only the simulation results from the first layer, representative of ground level, were used for the analysis in this study.

The meteorological fields were derived from NCEP FNL (Final) Operational Global Analysis data (NCEP, 2000) using the Weather Research and Forecasting Model (WRF, version 3.7) (Skamarock et al., 2008), with the MODIS land use database (Friedl et al., 2010) and the the Yonsei University (YSU) parametrization (Hong et al., 2006) for the planetary boundary layer. The WSM3 scheme (Hong et al., 2004) was used for the microphysics option of WRF, and the KainFritsch convective parametrization (Kain, 2004) was used for cumulus physics. These fields were then processed using version 4.3 of Meteorology-Chemistry Interface Processor (MCIP) (Otte and Pleim, 2010). The initial and boundary conditions were obtained from the Model for Ozone and Related Chemical Tracers (MOZART v2.0) (Horowitz et al., 2003). Emissions were generated based on the 2014 National Emissions Inventory (NEI) (US EPA, 2017a) and processed by the Sparse Matrix Operator Kernel Emission (SMOKE, version 4.5) processor (US EPA, 2017b). Biogenic emissions were obtained from the Biogenic Emission Inventory System (BEIS) (Pierce and Waldruff, 1991), and emissions from cars, trucks, and motorcycles were calculated with MOBILE6 (US EPA, 2003).

In this study, the AERO6 module in CMAQ was updated to simulate the heterogeneous uptake of $\mathrm{NH}_{3}$ by SOA. AERO6 
used the modal representation to simulate aerosol dynamics (Binkowski and Roselle, 2003). The size distribution of the aerosol particles is represented by three log-normal modes: the Aitken mode (size up to approximately $0.1 \mu \mathrm{m}$ ), the accumulation mode (size between 0.1 to $2.5 \mu \mathrm{m}$ ), and the coarse mode (size between 2.5 to $10 \mu \mathrm{m}$ ). The particles are assumed to be internally mixed within each mode. In the AERO6 modal approach, three integral properties of the size distribution are followed for mode $j$ : the total particle number concentration $N_{j}$, the total wet surface area concentration $S_{j}$, and the total mass concentration $m_{i j}$ of each individual chemical component $i$. In order to calculate the total uptake of $\mathrm{NH}_{3}$ by $\mathrm{SOA}$, one must know the representative wet surface area concentration of SOA ( $S_{\mathrm{SOA}}$ ) (SOA hygroscopic growth is not considered in the model), which can be calculated as follows (assuming a uniform density across different chemical components):

$S_{\mathrm{SOA}}=\sum_{j=1}^{x}\left(S_{j} \times \frac{\sum_{i=1}^{y} m_{i j}}{\sum_{k=1}^{z} m_{k j}}\right)$,

where $y$ is the total number of SOA species in mode $j, z$ is the total number of aerosol species in mode $j$, and $x$ is the total number of modes that contain SOA species. Here, $x=2$ since SOAs only exist in the Aitken mode and the accumulation mode. From $S_{\mathrm{SOA}}$ the first-order rate of $\mathrm{NH}_{3}$ uptake can be calculated as

$k=\gamma \times \frac{v_{\mathrm{NH}_{3}} \times S_{\mathrm{SOA}}}{4}$,

where $\gamma$ is the reactive uptake coefficient for ammonia and $v_{\mathrm{NH}_{3}}$ is the average speed of $\mathrm{NH}_{3}$ molecules $\left(609 \mathrm{~m} \mathrm{~s}^{-1}\right.$ at $298 \mathrm{~K})$. The above calculations were performed separately for each grid cell at every time step to obtain the effective first-order rate constant for each individual cell at each time step. The first-order rate constant of $\mathrm{NH}_{3}$ uptake was then multiplied by the gas-phase $\mathrm{NH}_{3}$ concentration to determine the loss rate of $\mathrm{NH}_{3}$ in each cell at each time step.

In this study, all $\mathrm{NH}_{3}$ taken up by $\mathrm{SOA}$ carbonyls is assumed to form NOCs, such as secondary imines and heteroaromatic compounds (Laskin et al., 2015). In this reaction, the carbonyl group of an SOA compound is converted into an imine group and a molecule of water is produced as a by-product. The imine product can further react by an intermolecular cyclization to produce heterocyclic organic compounds, with a loss of an additional water molecule (Laskin et al., 2014). The difference in molecular weights of two $\mathrm{H}_{2} \mathrm{O}$ molecules and one $\mathrm{NH}_{3}$ molecule $\left(2 \times 18-17=19 \mathrm{~g} \mathrm{~mol}^{-1}\right)$ is small relative to a molecular weight of a typical SOA compound (about $200 \mathrm{~g} \mathrm{~mol}^{-1}$ ). Therefore, for the sake of simplicity, we neglected the loss of the mass of particulate organics mass directly due to the $\mathrm{NH}_{3}$ uptake in this simulation. This assumption is supported by experimental observations described by Horne et al. (2018), in which SOA particles exposed to ammonia in a smog chamber did not change their size distribution but showed clear evidence of incorporation of organic nitrogen into the particles in online and offline mass spectra. Although, the $\mathrm{NH}_{3}$ uptake process does not directly impact the mass of SOA, the conversion of $\mathrm{NH}_{3}$ into NOCs can affect the SOA mass indirectly due to particle acidity changes. The particle acidity is altered because strongly basic $\mathrm{NH}_{3}$, which is converted into weakly basic NOCs, is no longer available to form inorganic salts of $\mathrm{NH}_{4}^{+}$. As the extent of neutralization of inorganic acids with $\mathrm{NH}_{3}$ is reduced, the particle acidity may increase. Figure S1 in the Supplement shows a schematic representation of the $\mathrm{NH}_{3}$ reactions considered in the model, including reversible function of inorganic salts and irreversible formation of NOCs. The ability of NOCs to neutralize inorganic acids to form salts is not considered (see Fig. S1) because NOCs are generally much weaker bases (e.g., imine $\mathrm{pK}_{b} \sim 10$, pyrrole $\mathrm{pK}_{b}=13.6$, pyridine $\left.\mathrm{pK}_{b}=8.8\right)$ compared to $\mathrm{NH}_{3}\left(\mathrm{pK}_{b}=4.8\right)$. In other words, once $\mathrm{NH}_{3}$ is converted into NOCs, it is no longer available to make inorganic salts of nitrate and sulfate.

As current laboratory data are not detailed enough to model the chemical uptake coefficient of ammonia by individual SOA species explicitly, a range of uptake coefficients was selected and applied to all SOA species. In the future, this approach can be refined by adopting more explicit reactions between ammonia and various types of SOA compounds. The ammonia uptake coefficients $(\gamma)$ used in this study were based on the values reported in the work of Liu et al. (2015), as well as the maximum possible extended conversion of SOA carbonyls into NOCs. Liu et al. (2015) reported a range of possible uptake coefficients from $10^{-5}$ to $10^{-2}$. However, some of our initial modeling tests showed that the use of a $10^{-2}$ uptake coefficient value would lead to an unrealistic amount of $\mathrm{NH}_{3}$ taken up by $\mathrm{SOA}$, where within a single time step the number of moles of $\mathrm{NH}_{3}$ taken up exceeded $10 \%$ of the total moles of SOA in one grid cell. Experiments (Liu et al., 2015; Horne et al., 2018) suggest that only $10 \%$ or less of SOA molecules can react with $\mathrm{NH}_{3}$ to form nitrogen-containing organic compounds. Additionally, in the study of Liu et al. (2015), the uptake coefficients are measured based on only a few SOA species (SOA formed from ozonolysis of $\alpha$-pinene and $\mathrm{OH}$ oxidation of $m$-xylene); other SOA species might not have the same reactivity. Furthermore, the highest value of the uptake coefficient was only observed at the initial period of the experiment of Liu et al. (2015) and decreased rapidly over time. Based on the considerations above, an uptake coefficient of $10^{-3}$ was considered a more reasonable upper limit value for our application instead of $10^{-2}$. Thus, four simulations were performed for each period to investigate the sensitivity of $\mathrm{NH}_{3}$ removal to changes in the uptake coefficient: (a) base case with no $\mathrm{NH}_{3}$ uptake, (b) $\mathrm{NH}_{3}$ uptake with $\gamma=10^{-3}$, (c) $\mathrm{NH}_{3}$ uptake with $\gamma=10^{-4}$, and (d) $\mathrm{NH}_{3}$ uptake with $\gamma=10^{-5}$. 
Results from each simulation were evaluated by comparing with observations from multiple monitoring networks. Then simulation results for scenario (b)-(d) are compared to the base case results in (a) to determine the impact of different uptake coefficients on different gas- and particlephase species. The value of $\gamma$ was assumed to remain constant in each scenario (i.e., no saturation or aging effects), which means each scenario represents an upper limit for the amount of $\mathrm{NH}_{3}$ that would be taken up by SOA with the chosen value of the uptake coefficient. No further changes were made to the model or its inputs between each scenario. Results of the first 7 days of each simulations were discarded as a model spin-up period to minimize the effect of initial conditions and allow sufficient time for the $\mathrm{NH}_{3}$ removal process to occur.

\section{Results and discussion}

\subsection{Model validation}

First, base case simulation results of $\mathrm{PM}_{2.5}, \mathrm{PM}_{10}$, and $\mathrm{O}_{3}$ are compared with the observations from the US Environmental Protection Agency's Air Quality System (AQS) to evaluate the model performance. The AQS network (https://www.epa. gov/aqs) is geographically diverse and spans the entire US. It is also an excellent source of quality-assured measurements, with hourly recorded concentrations for $\mathrm{PM}_{2.5}, \mathrm{PM}_{10}$, and $\mathrm{O}_{3}$. The statistical parameters used in this study are the mean normalized gross bias (MNGB), mean normalized gross error (MNGE), mean fractional bias (MFB), and mean fractional error (MFE). Definitions of these parameters are presented precisely in Table S1 in the Supplement.

Table 1 shows good model performance for $\mathrm{O}_{3}$, as the statistics meet the recommended performance criteria $(|\mathrm{MNGB}| \leq 15 \%$ and $\mathrm{MNGE} \leq 30 \%$ ) (Russell and Dennis, 2000). Additionally, the maps of MNGB values of $\mathrm{O}_{3}$ measured by individual stations are available in Fig. S2. This maps show that most of the stations have low bias with some underestimation over the northeast in the winter and some general overestimation around the country in the summer. Only the two base case simulations are shown in Table 1 and Fig. S2, because the change in the $\mathrm{NH}_{3}$ uptake coefficient has no impact on $\mathrm{O}_{3}$ in the model. Table 2 shows the statistics for $\mathrm{PM}_{2.5}$ for both the summer and winter. Cases satisfied the model performance criteria proposed by Boylan and Russell (2006) with MFE $\leq 75 \%$ and $|\mathrm{MFB}| \leq 60 \%$. Additionally, the maps of MFB values of $\mathrm{PM}_{2.5}$ measured by individual stations are available in Fig. S3. The model performance for winter is much better than for the summer, as the amount of $\mathrm{PM}_{2.5}$ is overestimated during the summer. The impact of different $\mathrm{NH}_{3}$ uptake coefficients on $\mathrm{PM}_{2.5}$ is also reflected in the statistics. For the winter, increasing the $\mathrm{NH}_{3}$ uptake coefficient leads to a decrease in the total $\mathrm{PM}_{2.5}$ and a slightly better model performance when compared to
Table 1. Comparison between the base case simulation results for $\mathrm{O}_{3}$ and observations from the AQS network. (Obs. stands for observation. Sim. stands for simulation. Corr. stands for correlation. No. sites means number of observation sites used for statistics.)

\begin{tabular}{lccccrrr}
\hline Period & $\begin{array}{c}\text { Obs. } \\
\text { mean } \\
\mathrm{ppb}\end{array}$ & $\begin{array}{c}\text { Sim. } \\
\text { mean } \\
\mathrm{ppb}\end{array}$ & $\begin{array}{c}\text { RMSE } \\
\mathrm{ppb}\end{array}$ & $\begin{array}{c}\text { Corr. } \\
\%\end{array}$ & $\begin{array}{r}\text { MNGB } \\
\%\end{array}$ & $\begin{array}{c}\text { MNGE } \\
\%\end{array}$ & $\begin{array}{r}\text { No. } \\
\text { sites }\end{array}$ \\
\hline Summer & 41.1 & 50.9 & 16.7 & 56.7 & 12.0 & 29.7 & 1262 \\
Winter & 27.3 & 33.9 & 10.4 & 51.4 & 8.8 & 23.1 & 664 \\
\hline
\end{tabular}

the observations. On the contrary, larger $\mathrm{NH}_{3}$ uptake coefficients cause higher $\mathrm{PM}_{2.5}$ concentration during the summer, resulting in larger discrepancies compared with measurements. The reasons for such seasonal differences will be analyzed in Sect. 3.2.4. The statistics of $\mathrm{PM}_{10}$ show much closer agreement between the simulation results and the observations than $\mathrm{PM}_{2.5}$, as shown on Table S2, with the MFB values for each site mapped in Fig. S4. The MFE is similar to that of $\mathrm{PM}_{2.5}$, while much smaller MFB values are found for the summer. Similar to $\mathrm{PM}_{2.5}$, the increase in the $\mathrm{NH}_{3}$ uptake coefficient leads to a lower $\mathrm{PM}_{10}$ concentration for the winter, but a higher $\mathrm{PM}_{10}$ concentration for the summer. One possible explanation for the different performance between $\mathrm{PM}_{2.5}$ and $\mathrm{PM}_{10}$ could be the underestimation of coarse-mode particles due to the mode-species limitation of CMAQ. Most of the SOA species are not allowed to grow into the coarse mode and their mass could be trapped in the accumulation mode and therefore cause this overestimation.

Second, the simulated concentration of gas-phase $\mathrm{NH}_{3}$ is compared to observation data from the Ammonia Monitoring Network (AMoN). In each AMoN site, samples are deployed for 2-week periods. Details about the network and its sampling method can be found on NADP (2014). Table 3 shows the statistics between each simulation case and the measurement data, and the MFB values for ammonia measured by individual stations are presented in Fig. S5. The seasonal influence is quite clear in the statistics of the two base case simulations. Similar to $\mathrm{PM}_{2.5}$, the model overestimates the $\mathrm{NH}_{3}$ concentration for the summer, especially over the southeast and the Central Valley regions of California. On the contrary, the simulated $\mathrm{NH}_{3}$ concentration is underestimated for the winter. The impacts of different $\mathrm{NH}_{3}$ uptake coefficients on $\mathrm{NH}_{3}$ concentrations are consistent between the winter and the summer; the $\mathrm{NH}_{3}$ concentration decreases as the uptake coefficient increases. However, such impact is much more significant during the summer than the winter. Figure S6 shows the difference in MFE between the base cases and cases with different assumed values for $\mathrm{NH}_{3}$ uptake coefficients. For the winter cases, the overall impact on model performance is negligible. For the summer cases, improvements in model performance can be found in the southeast and the Central Valley regions of California. The choice of the $\gamma=10^{-4}$ appears to provide the greatest model per- 
Table 2. Comparison between simulation results for $\mathrm{PM}_{2.5}$ and observations from the AQS network. (Obs. stands for observation. Sim. stands for simulation. Corr. stands for correlation. No. sites means number of observation sites used for statistics.)

\begin{tabular}{llccccccc}
\hline Scenario & Period & $\begin{array}{c}\text { Obs. mean } \\
\mu \mathrm{g} \mathrm{m}^{-3}\end{array}$ & $\begin{array}{c}\text { Sim. mean } \\
\mu \mathrm{g} \mathrm{m}^{-3}\end{array}$ & $\begin{array}{c}\text { RMSE } \\
\mu \mathrm{g} \mathrm{m}^{-3}\end{array}$ & $\begin{array}{c}\text { Corr. } \\
\%\end{array}$ & $\begin{array}{c}\text { MFB } \\
\%\end{array}$ & $\begin{array}{c}\text { MFE } \\
\%\end{array}$ & $\begin{array}{c}\text { No. } \\
\text { sites }\end{array}$ \\
\hline Base & Summer & 12.6 & 21.9 & 18.1 & 17.8 & 36.7 & 62.7 & 176 \\
$\gamma=10^{-3}$ & Summer & 12.6 & 24.1 & 20.5 & 18.3 & 41.2 & 66.3 & 176 \\
$\gamma=10^{-4}$ & Summer & 12.6 & 22.1 & 18.4 & 17.8 & 37.2 & 63.1 & 176 \\
$\gamma=10^{-5}$ & Summer & 12.6 & 21.9 & 18.1 & 17.8 & 37.0 & 62.9 & 176 \\
Base & Winter & 12.3 & 13.0 & 11.4 & 31.3 & 2.8 & 60.9 & 166 \\
$\gamma=10^{-3}$ & Winter & 12.3 & 12.6 & 11.1 & 31.4 & 0.6 & 60.4 & 166 \\
$\gamma=10^{-4}$ & Winter & 12.3 & 12.9 & 11.4 & 31.4 & 2.4 & 60.8 & 166 \\
$\gamma=10^{-5}$ & Winter & 12.3 & 13.0 & 11.4 & 31.3 & 2.7 & 60.9 & 166 \\
\hline
\end{tabular}

Table 3. Comparison between simulation results for $\mathrm{NH}_{3}$ and observations from the AMoN network. (Obs. stands for observation. Sim. stands for simulation. Corr. stands for correlation. No. sites means number of observation sites used for statistics.)

\begin{tabular}{llcccrrrr}
\hline Scenario & Period & $\begin{array}{r}\text { Obs. mean } \\
\mu \mathrm{g} \mathrm{m}^{-3}\end{array}$ & $\begin{array}{c}\text { Sim. mean } \\
\mu \mathrm{g} \mathrm{m}^{-3}\end{array}$ & $\begin{array}{r}\text { RMSE } \\
\mu \mathrm{g} \mathrm{m}^{-3}\end{array}$ & $\begin{array}{r}\text { Corr. } \\
\%\end{array}$ & $\begin{array}{r}\text { MFB } \\
\%\end{array}$ & $\begin{array}{r}\text { MFE } \\
\%\end{array}$ & $\begin{array}{c}\text { No. } \\
\text { sites }\end{array}$ \\
\hline Base & Summer & 1.36 & 2.17 & 1.41 & 20.2 & 46.7 & 72.2 & 46 \\
$\gamma=10^{-3}$ & Summer & 1.36 & 0.63 & 1.07 & -26.1 & -70.1 & 96.4 & 46 \\
$\gamma=10^{-4}$ & Summer & 1.36 & 1.48 & 1.08 & -2.0 & 7.3 & 63.2 & 46 \\
$\gamma=10^{-5}$ & Summer & 1.36 & 1.30 & 1.30 & 18.1 & 38.0 & 68.9 & 46 \\
Base & Winter & 0.77 & 0.37 & 0.57 & 26.2 & -63.3 & 88.7 & 19 \\
$\gamma=10^{-3}$ & Winter & 0.77 & 0.31 & 0.60 & 29.7 & -78.9 & 98.0 & 19 \\
$\gamma=10^{-4}$ & Winter & 0.77 & 0.36 & 0.58 & 27.5 & -65.9 & 90.1 & 19 \\
$\gamma=10^{-5}$ & Winter & 0.77 & 0.37 & 0.57 & 26.5 & -63.6 & 88.9 & 19 \\
\hline
\end{tabular}

formance improvement in the summer, based on both Table 3 and Fig. S6.

Finally, simulation results of individual inorganic aerosol compounds (e.g., $\mathrm{NH}_{4}^{+}, \mathrm{SO}_{4}^{2-}$, and $\mathrm{NO}_{3}^{-}$) are also compared with measurement data obtained from the EPA's Chemical Speciation Network (CSN). The CSN network collects $24 \mathrm{~h}$ integrated samples every day (midnight to midnight) of major fine-particle chemical components and most of the CSN sites are in urban areas. A detailed description of the network and its sampling protocol are available in Malm et al. (2004). The statistics for $\mathrm{SO}_{4}^{2-}$ presented in Table $\mathrm{S} 3$ with the maps of MFB values for all individual sites (Fig. S11) indicate good model performance. There is good agreement between mean observed and simulated concentrations with small MFB and MFE values that satisfy the model performance goals proposed by Boylan and Russell (2006) $(|\mathrm{MFB}| \leq 30 \%$ and $\mathrm{MFE} \leq 50 \%)$. The statistics of other scenarios are not presented in the table, as the change in the $\mathrm{NH}_{3}$ uptake coefficient shows no observable impact on the $\mathrm{SO}_{4}^{2-}$ statistics. This is due to the extremely low volatility of sulfuric acid, which forces almost the entire $\mathrm{SO}_{4}^{2-}$ to be condensed into the aerosol phase, regardless of the concentration of $\mathrm{NH}_{3}$.

For $\mathrm{NH}_{4}^{+}$(Table 4), in general, the statistics show a good model performance, as the MFB and MFE satisfied the model performance criteria proposed by Boylan and Russell (2006) in all eight scenarios. Additionally, Fig. S7 shows the level of bias (MFB) of individual CSN sites for the base case, which shows $\mathrm{NH}_{4}^{+}$is considerably overestimated over the southeast but underestimated in the midwest regions of the country for both winter and summer. Based on Table 4, the $\mathrm{NH}_{4}^{+}$ is slightly overestimated in the base case for the summer period; however, the addition of $\mathrm{NH}_{3}$ uptake leads to a lower modeled $\mathrm{NH}_{4}^{+}$concentration and reduced level of overestimation. Such improvements happen over most of the eastern US as well as the Central Valley of California, based on Fig. S8b and d, which present the difference in MFE between the base cases and cases with $\mathrm{NH}_{3}$ uptake coefficients. Similar to $\mathrm{NH}_{3}$, the $\gamma=10^{-4}$ case shows better model performance improvement than the $\gamma=10^{-3}$ case in the summer. For the winter, the $\mathrm{NH}_{4}^{+}$concentration is slightly underestimated in the base case, so the decrease in the $\mathrm{NH}_{4}^{+}$concentration caused by the increase in the $\mathrm{NH}_{3}$ uptake coefficient leads to an even larger underestimation. As shown on Fig. S8a and c, model performance is not improved in most of the stations, except over the southeast region.

Table 5 gives the statistics for $\mathrm{NO}_{3}^{-}$. In general, the model overestimates the $\mathrm{NO}_{3}^{-}$concentration for both periods, and a poor correlation is found for the summer. The relatively poor model performance with respect to $\mathrm{NO}_{3}^{-}$is consistent with previous CMAQ studies (Eder and Yu, 2006; Appel 
Table 4. Comparison between simulation results for $\mathrm{NH}_{4}^{+}$and observations from the CSN network. (Obs. stands for observation. Sim. stands for simulation. Corr. stands for correlation. No. sites means number of observation sites used for statistics.)

\begin{tabular}{llccccccc}
\hline Scenario & Period & $\begin{array}{c}\text { Obs. mean } \\
\mu \mathrm{g} \mathrm{m}^{-3}\end{array}$ & $\begin{array}{c}\text { Sim. mean } \\
\mu \mathrm{g} \mathrm{m}^{-3}\end{array}$ & $\begin{array}{r}\text { RMSE } \\
\mu \mathrm{g} \mathrm{m}^{-3}\end{array}$ & $\begin{array}{c}\text { Corr. } \\
\%\end{array}$ & $\begin{array}{r}\text { MFB } \\
\%\end{array}$ & $\begin{array}{c}\text { MFE } \\
\%\end{array}$ & $\begin{array}{c}\text { No. } \\
\text { sites }\end{array}$ \\
\hline Base & Summer & 0.82 & 0.98 & 0.70 & 31.8 & 7.7 & 71.3 & 187 \\
$\gamma=10^{-3}$ & Summer & 0.82 & 0.83 & 0.62 & 31.4 & -5.3 & 70.3 & 187 \\
$\gamma=10^{-4}$ & Summer & 0.82 & 0.92 & 0.66 & 32.0 & 3.2 & 70.5 & 187 \\
$\gamma=10^{-5}$ & Summer & 0.82 & 0.96 & 0.69 & 31.9 & 6.8 & 71.1 & 187 \\
Base & Winter & 1.30 & 1.20 & 0.96 & 45.8 & -12.8 & 64.5 & 187 \\
$\gamma=10^{-3}$ & Winter & 1.30 & 1.08 & 0.93 & 45.1 & -21.1 & 64.3 & 187 \\
$\gamma=10^{-4}$ & Winter & 1.30 & 1.18 & 0.95 & 45.6 & -14.1 & 64.4 & 187 \\
$\gamma=10^{-5}$ & Winter & 1.30 & 1.20 & 0.96 & 45.8 & -12.9 & 64.4 & 187 \\
\hline
\end{tabular}

Table 5. Comparison between simulation results for $\mathrm{NO}_{3}^{-}$and observations from the CSN network. (Obs. stands for observation. Sim. stands for simulation. Corr. stands for correlation. No. sites means number of observation sites used for statistics.)

\begin{tabular}{llccccccc}
\hline Scenario & Period & $\begin{array}{c}\text { Obs. mean } \\
\mu \mathrm{g} \mathrm{m}^{-3}\end{array}$ & $\begin{array}{c}\text { Sim. mean } \\
\mu \mathrm{g} \mathrm{m}^{-3}\end{array}$ & $\begin{array}{r}\text { RMSE } \\
\mu \mathrm{g} \mathrm{m}^{-3}\end{array}$ & $\begin{array}{c}\text { Corr. } \\
\%\end{array}$ & $\begin{array}{r}\text { MFB } \\
\%\end{array}$ & $\begin{array}{c}\text { MFE } \\
\%\end{array}$ & $\begin{array}{c}\text { No. } \\
\text { sites }\end{array}$ \\
\hline Base & Summer & 0.47 & 0.88 & 0.85 & 17.8 & 31.1 & 87.3 & 187 \\
$\gamma=10^{-3}$ & Summer & 0.47 & 0.46 & 0.54 & 14.7 & -38.2 & 90.1 & 187 \\
$\gamma=10^{-4}$ & Summer & 0.47 & 0.70 & 0.68 & 18.2 & 10.3 & 80.6 & 187 \\
$\gamma=10^{-5}$ & Summer & 0.47 & 0.84 & 0.81 & 18.1 & 27.6 & 85.8 & 187 \\
Base & Winter & 2.43 & 3.14 & 2.57 & 40.4 & 31.0 & 75.2 & 187 \\
$\gamma=10^{-3}$ & Winter & 2.43 & 2.74 & 2.29 & 40.0 & 20.5 & 71.0 & 187 \\
$\gamma=10^{-4}$ & Winter & 2.43 & 3.07 & 2.52 & 40.4 & 29.3 & 74.4 & 187 \\
$\gamma=10^{-5}$ & Winter & 2.43 & 3.13 & 2.56 & 40.4 & 30.8 & 75.1 & 187 \\
\hline
\end{tabular}

et al., 2008). The addition of the $\mathrm{NH}_{3}$ uptake coefficient reduces the simulated $\mathrm{NO}_{3}^{-}$concentration significantly. The $\gamma=10^{-3}$ case leads to a mean $\mathrm{NO}_{3}^{-}$concentration which is much closer to the observed average than the base case in both simulated periods. Figure S9 shows the maps of MFB values for particulate nitrate measured by each station in the base cases. We find that the modeled $\mathrm{NO}_{3}^{-}$is overestimated over the southeast region for both periods and also overestimated along the Central Valley of California during the summer period. The addition of $\mathrm{NH}_{3}$ uptake reduced such overestimation and improved the model performance in those regions as shown in Fig. S10, which presents the difference in MFE between base cases and cases with different $\mathrm{NH}_{3}$ uptake included. For the winter period, it is clear the $\gamma=10^{-3}$ case provides better model performance. For the summer period, the model performance improvement occurred on more observation sites in the $\gamma=10^{-4}$ case than the $\gamma=10^{-3}$ case. However, the $\gamma=10^{-3}$ case provides better improvement at some sites, although more sites suffer performance deterioration compared to the $\gamma=10^{-4}$ case. In summary, the model tends to perform better on the whole with $\mathrm{NH}_{3}$ uptake in SOA included with $\gamma \sim 10^{-3}$ to $10^{-4}$.

\subsection{Air quality impacts}

\subsubsection{Impact on gas-phase $\mathrm{NH}_{3}$ and $\mathrm{HNO}_{3}$ concentrations}

Figure S12 shows the time series of daily domain-averaged (averaged over $24 \mathrm{~h}$ and the simulation domain) $\mathrm{NH}_{3}$ for both the winter and summer, for different uptake coefficient values. In general, the $\mathrm{NH}_{3}$ concentration is reduced after the introduction of the SOA-based $\mathrm{NH}_{3}$ uptake process. The magnitude of the reduction is increased as the uptake coefficient increases. For the winter, the spatiotemporally averaged (averaged over entire period and the simulation domain) $\mathrm{NH}_{3}$ concentration for the base case is $0.44 \mathrm{ppb}$, while the value decreases to $0.43 \mathrm{ppb}(-2.3 \%)$ for the $\gamma=10^{-5}$ case, $0.41 \mathrm{ppb}(-6.8 \%)$ for the $\gamma=10^{-4}$ case, and $0.31 \mathrm{ppb}$ $(-29.5 \%)$ for the $\gamma=10^{-3}$ case. For the summer, the spatiotemporally averaged $\mathrm{NH}_{3}$ concentration for the base case is $2.30 \mathrm{ppb}$, while the value decreases to $2.10 \mathrm{ppb}(-8.7 \%)$ for the $\gamma=10^{-5}$ case, $1.58 \mathrm{ppb}(-31.3 \%)$ for the $\gamma=10^{-4}$ case, and $0.76 \mathrm{ppb}(-67.0 \%)$ for the $\gamma=10^{-3}$ case. The impact of the uptake process is higher for the summer due to larger SOA concentrations during the summer (spatiotemporally averaged $9.25 \mu \mathrm{g} \mathrm{m}^{-3}$ for the base case) than the winter (spatiotemporally averaged $2.72 \mu \mathrm{g} \mathrm{m}^{-3}$ for the base case). 

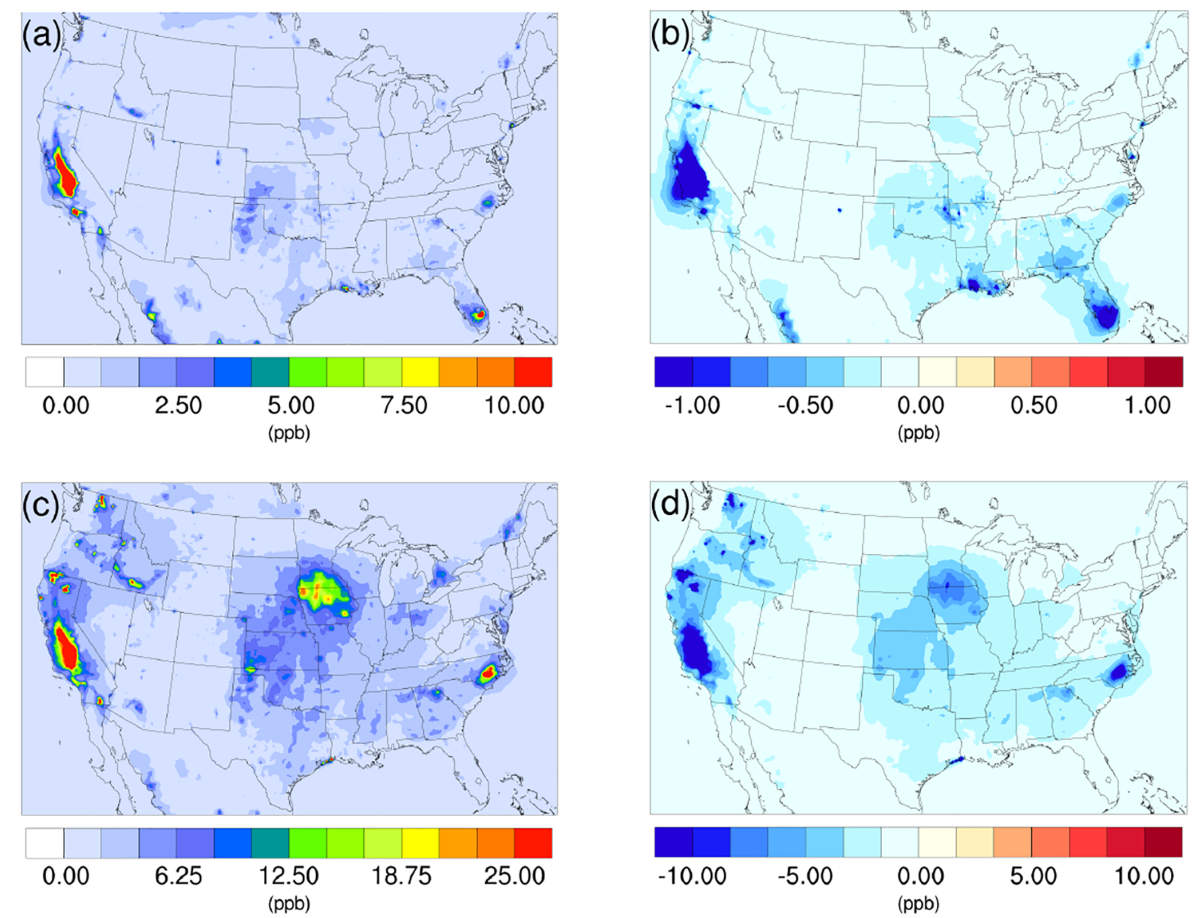

Figure 1. Spatial distribution of time-averaged $\mathrm{NH}_{3}$ concentrations in the base case for (a) winter and (c) summer. Spatial distribution of the difference in time-averaged $\mathrm{NH}_{3}$ concentrations between the $\gamma=10^{-3}$ case and the base case for (b) winter and (d) summer. Negative values represent decreases in concentration with respect to the base case.

The spatial distribution of the impact over the simulated domain is also investigated. Figure 1a and c show the timeaveraged spatial distribution of $\mathrm{NH}_{3}$ for the winter and summer base cases, while the differences between the $\gamma=10^{-3}$ case and the base case are shown in Fig. $1 \mathrm{~b}$ and d. For both periods, the Central Valley of California is a hotspot for $\mathrm{NH}_{3}$ emissions, and the region exhibits the most significant impact due to the introduction of the new $\mathrm{NH}_{3}$ uptake mechanism. This is due to the intensive agricultural activities in this region including the heavy application of fertilizers (Krauter et al., 2002) and the year-round farming pattern supported by California's relatively warm climate. The hog farm industry is largely responsible for the high $\mathrm{NH}_{3}$ concentration, in North Carolina and north Iowa in the summer, where significant $\mathrm{NH}_{3}$ loss can also be spotted in the $\gamma=10^{-3}$ case. Agriculture and wild fires also produce some hotspots of ammonia concentration in others areas, such as southern Florida in the winter and several locations in northern California and Washington states, where $\mathrm{NH}_{3}$ concentrations also decreased significantly in the $\gamma=10^{-3}$ case. The spatial distribution of differences between the base case and the $\gamma=10^{-4}$ and $\gamma=10^{-5}$ cases is similar to the $\gamma=10^{-3}$ only with different scales. These differences are shown in Fig. S13.

As the condensation of $\mathrm{HNO}_{3}$ into the particle phase is directly associated with $\mathrm{NH}_{3}$ concentration, it is reasonable to infer that the introduction of the $\mathrm{NH}_{3}$ uptake mechanism could also impact the concentration of $\mathrm{HNO}_{3}$. Figure S14 shows the time series of daily-averaged $\mathrm{HNO}_{3}$ for both the winter and summer. In contrast to $\mathrm{NH}_{3}$, the integration of the $\mathrm{NH}_{3}$ uptake mechanism leads to an increase in $\mathrm{HNO}_{3}$ concentration, and the scale of magnitude of the increase rises as the uptake coefficient is increased, although its scale of variation is much smaller than that of $\mathrm{NH}_{3}$. For the winter, the difference between the base case and the $\gamma=10^{-5}$ case is very small $(<0.2 \%)$ and remains insignificant for the $\gamma=10^{-4}$ case $(\sim 1.2 \%)$. Only the $\gamma=10^{-3}$ case shows a significant increase in $\mathrm{HNO}_{3}$ as concentrations increase by $8.5 \%$ (the spatiotemporally averaged concentration is $0.27 \mathrm{ppb}$ for the base case and $0.30 \mathrm{ppb}$ for the $\gamma=10^{-3}$ case). Similar to the $\mathrm{NH}_{3}$ variation, the impact becomes larger for the summer, where the spatiotemporally averaged $\mathrm{HNO}_{3}$ concentration for the base case is $0.51 \mathrm{ppb}$, while the value increases by $2.0 \%(0.52 \mathrm{ppb})$ for the $\gamma=10^{-5}$ case, $7.8 \%(0.55 \mathrm{ppb})$ for the $\gamma=10^{-4}$, case, and $19.6 \%(0.61 \mathrm{ppb})$ for the $\gamma=10^{-3}$ case. These increase in $\mathrm{HNO}_{3}$ concentrations is due to the reduction in $\mathrm{NH}_{3}$ caused by the conversion of $\mathrm{NH}_{3}$ into NOCs, making less $\mathrm{NH}_{3}$ available for reaction with $\mathrm{HNO}_{3}$ to form the particle-phase $\mathrm{NH}_{4} \mathrm{NO}_{3}$.

The time-averaged spatial distributions of $\mathrm{HNO}_{3}$ for both the winter and summer base cases are presented in Fig. 2a and $\mathrm{c}$. The northeast region exhibits relatively high $\mathrm{HNO}_{3}$ concentration for both periods, largely due to the high $\mathrm{NO}_{x}$ $\left(\mathrm{NO}+\mathrm{NO}_{2}\right)$ emissions from transportation activities. The addition of the $\mathrm{NH}_{3}$ uptake process does not cause an ob- 

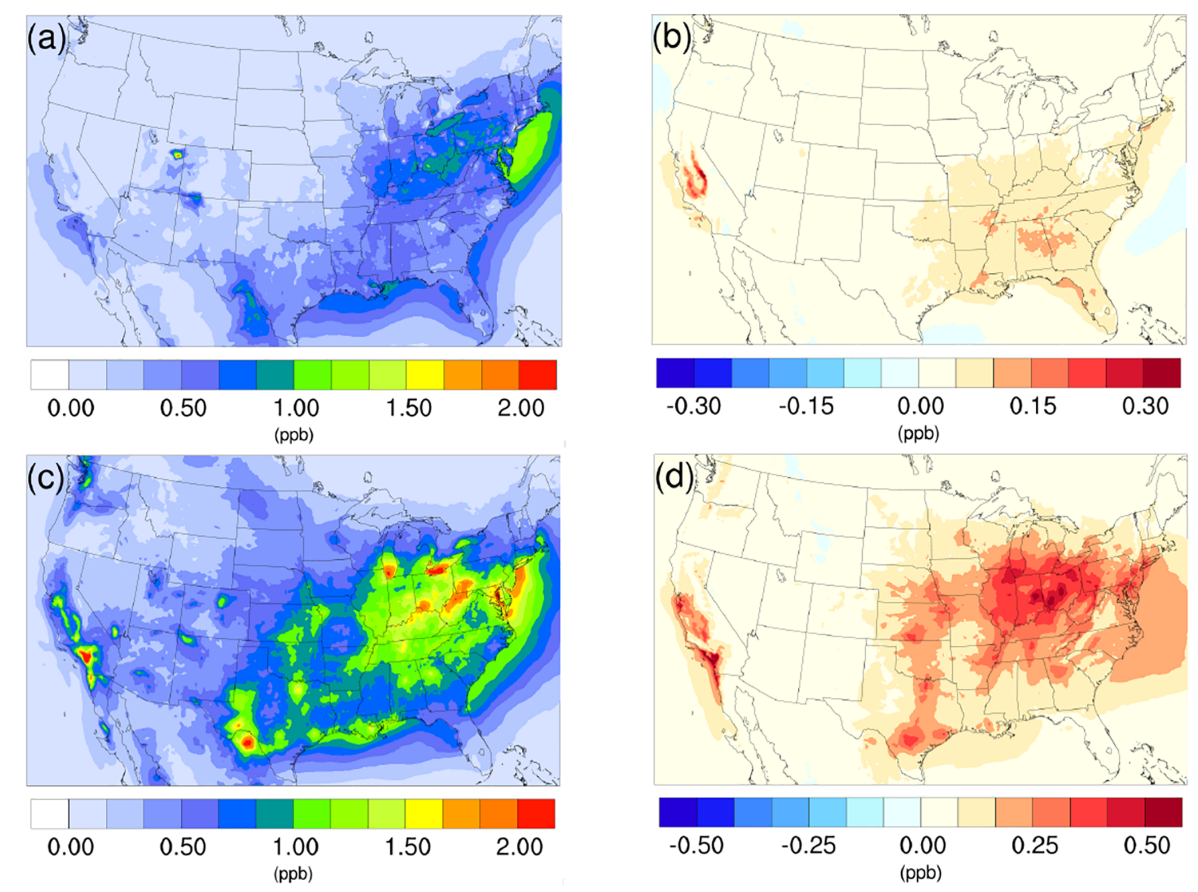

Figure 2. Spatial distribution of time-averaged $\mathrm{HNO}_{3}$ concentrations in the base case for (a) winter and (c) summer. Spatial distribution of the difference in time-averaged $\mathrm{HNO}_{3}$ concentrations between the $\gamma=10^{-3}$ case and the base case for (b) winter and (d) summer. Positive values represent increases in concentration with respect to the base case.

vious impact in this region for the winter, as the reduction of $\mathrm{NH}_{3}$ is very small (Fig. 1b) due to low SOA and $\mathrm{NH}_{3}$ concentrations in the base case. In contrast, the increase in $\mathrm{HNO}_{3}$ becomes much more significant for this region in the summer, as the loss of $\mathrm{NH}_{3}$ becomes greater due to larger $\mathrm{NH}_{3}$ and SOA concentrations in the base case. The winter hotspot around northeastern Utah (Uintah Basin) could be caused by the stagnant atmospheric conditions during the winter in the valley (Lee et al., 2014), which traps $\mathrm{NO}_{x}$ emitted from local and remote sources located on the east side of the valley. The resulting $\mathrm{NO}_{x}$ undergoes a nighttime reaction with $\mathrm{O}_{3}$, forming $\mathrm{N}_{2} \mathrm{O}_{5}$ (high $\mathrm{N}_{2} \mathrm{O}_{5}$ concentration is spotted in the model at the same place as shown on Fig. S24). Additionally, the lack of $\mathrm{NH}_{3}$ also favors the $\mathrm{HNO}_{3}$ accumulation, as a result, the addition of $\mathrm{NH}_{3}$ does not have much impact on this spot. The largest increase in $\mathrm{HNO}_{3}$ concentrations in winter is found over the Central Valley of California, which also corresponds to the largest $\mathrm{NH}_{3}$ reduction (Fig. 1b). For the summer, the largest impact occurs over the hotspot of southern California, where strong traffic emissions of $\mathrm{NO}_{x}$ and active photochemistry provide a strong $\mathrm{HNO}_{3}$ source. The significant reduction of $\mathrm{NH}_{3}$ concentration from the south Central Valley could reduce the potential sink of $\mathrm{HNO}_{3}$ into the particle phase and leave more $\mathrm{HNO}_{3}$ in the gas phase. The spatial distribution of differences between the base case and the $\gamma=10^{-4}$ and $\gamma=10^{-5}$ cases is similar to the $\gamma=10^{-3}$ only with different scales, and they can be found in Fig. S15.

\subsubsection{Impact on inorganic PM}

One of the effects of the gas-phase $\mathrm{NH}_{3}$ reduction due to the inclusion of SOA-based $\mathrm{NH}_{3}$ conversion to NOCs would be the decrease in the $\mathrm{NH}_{4}^{+}$concentration in the particle phase, as all $\mathrm{NH}_{4}^{+}$originates from gas-phase $\mathrm{NH}_{3}$. Figure $\mathrm{S} 16$ shows the spatiotemporal evolution of daily-averaged $\mathrm{NH}_{4}^{+}$ for the winter and the summer. In general, the addition of $\mathrm{NH}_{3}$ uptake in the model causes a decrease in particle-phase $\mathrm{NH}_{4}^{+}$concentration, and the impact is more significant for the summer than the winter. For the summer case, the average decrease in $\mathrm{NH}_{4}^{+}$is $1.8 \%$ for $\gamma=10^{-5}, 10.7 \%$ for $\gamma=10^{-4}$, and $28.2 \%$ for $\gamma=10^{-3}$; for the winter case, the average decrease is $0.2 \%$ for $\gamma=10^{-5}, 2.3 \%$ for $\gamma=10^{-4}$, and $13.2 \%$ for $\gamma=10^{-3}$. Such behavior corresponds well to the level of $\mathrm{NH}_{3}$ reduction in Fig. S12 and is caused by the higher SOA concentrations during the summer.

The time-averaged spatial distributions of the $\mathrm{NH}_{4}^{+}$concentration for both the winter and summer base case are shown on Fig. 3a and c. Most of the $\mathrm{NH}_{4}^{+}$is concentrated over the eastern part of the US, as a result of high $\mathrm{NH}_{3}$ concentrations (see Fig. 1) in this region combined with the abundance of $\mathrm{NH}_{3}$ neutralizers (e.g., $\mathrm{HNO}_{3}$ and $\mathrm{H}_{2} \mathrm{SO}_{4}$ ). Another hotspot is the Central Valley of California and the South Coast Air Basin of California (Nowak et al., 2012), resulting from high $\mathrm{NH}_{3}$ emissions from the intensive agriculture (Fig. 1). In the presence of both $\mathrm{HNO}_{3}$ and $\mathrm{H}_{2} \mathrm{SO}_{4}$, $\mathrm{NH}_{3}$ is first neutralized by $\mathrm{H}_{2} \mathrm{SO}_{4}$ to form either $\left(\mathrm{NH}_{4}\right)_{2} \mathrm{SO}_{4}$ 

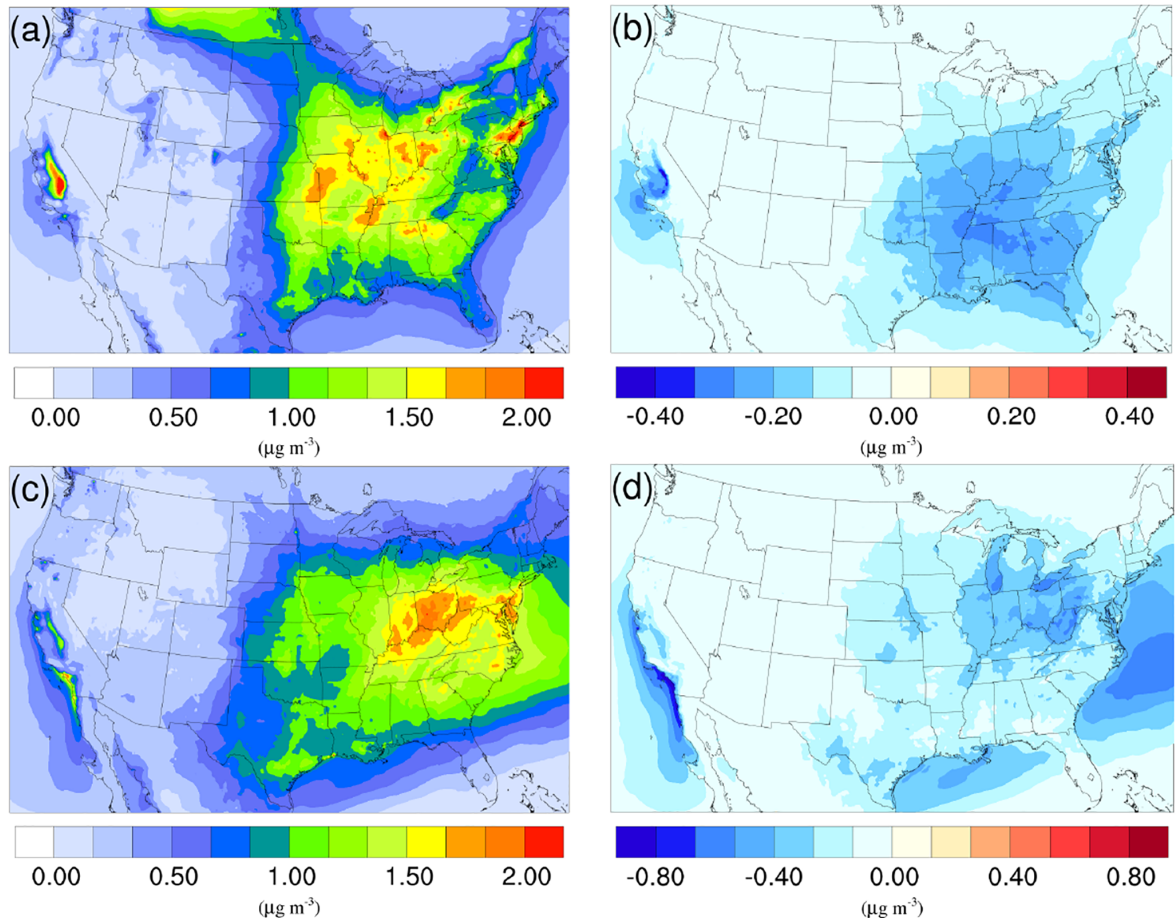

Figure 3. Spatial distribution of time-averaged $\mathrm{NH}_{4}^{+}$concentrations in the base case for (a) winter and (c) summer. Spatial distribution of the difference in time-averaged $\mathrm{NH}_{4}^{+}$concentrations between the $\gamma=10^{-3}$ case and the base case for (b) winter and (d) summer. Negative values represent decreases in concentration with respect to the base case.
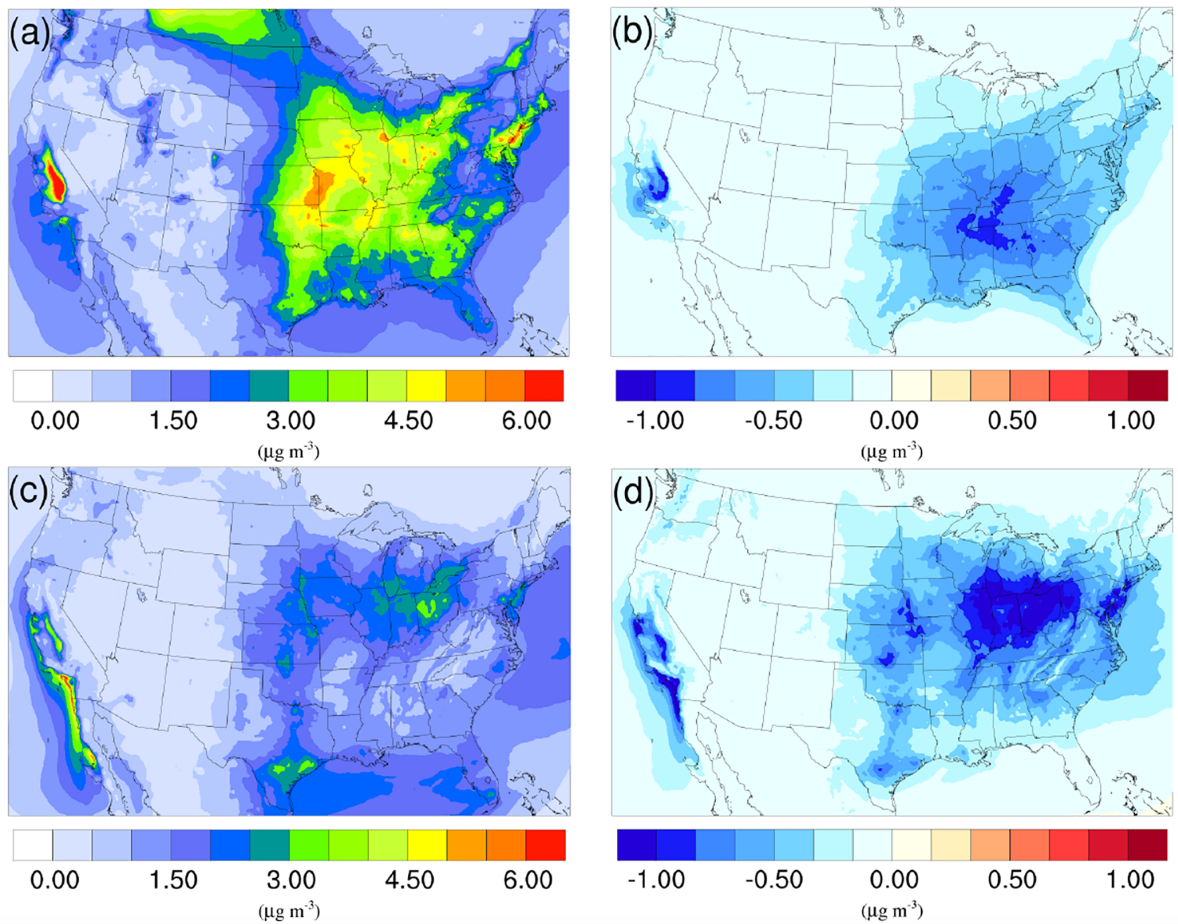

Figure 4. Spatial distribution of time-averaged $\mathrm{NO}_{3}^{-}$concentrations in the base case for (a) winter and (c) summer. Spatial distribution of the difference in time-averaged $\mathrm{NO}_{3}^{-}$concentrations between the $\gamma=10^{-3}$ case and the base case for (b) winter and (d) summer. Negative values represent decreases in concentration with respect to the base case. 

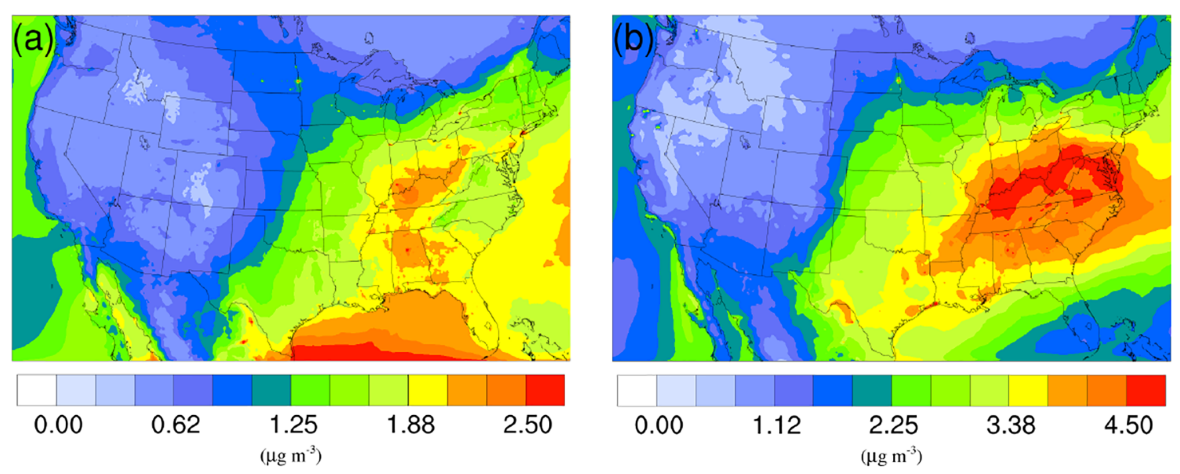

Figure 5. Spatial distribution of time-averaged $\mathrm{SO}_{4}^{2-}$ concentrations in the base case for (a) winter and (b) summer. The difference due to $\mathrm{NH}_{3}$ conversion into NOCs is not shown because it is very small.

or $\mathrm{NH}_{4} \mathrm{HSO}_{4}$ in the particle phase, while the rest of the $\mathrm{NH}_{3}$ reacts with $\mathrm{HNO}_{3}$ and forms particle-phase $\mathrm{NH}_{4} \mathrm{NO}_{3}$. The percentage of $\mathrm{NH}_{4}^{+}$associated with $\mathrm{NO}_{3}^{-}, \mathrm{SO}_{4}^{2-}$, and $\mathrm{HSO}_{4}^{-}$ could be investigated by comparing the spatial distribution of the $\mathrm{NO}_{3}^{-}$concentration for the corresponding period in Fig. $4 \mathrm{a}$ and $\mathrm{c}$ and the $\mathrm{SO}_{4}^{2-}$ in Fig. $5 \mathrm{a}$ and b. For the winter, the $\mathrm{H}_{2} \mathrm{SO}_{4}$ concentration is insufficient to neutralize all the $\mathrm{NH}_{3}$ for the mid-east region, so more $\mathrm{NO}_{3}^{-}$is involved in the $\mathrm{NH}_{3}$ neutralization, and there are more nitrate particles than sulfate particles. For the summer, as the sulfate concentration almost doubles over the mid-east US compared to the winter, most of the $\mathrm{NH}_{3}$ is neutralized by $\mathrm{H}_{2} \mathrm{SO}_{4}$. This causes an absence of $\mathrm{NO}_{3}^{-}$above this region and only appears on the surrounding region where sulfate concentration is low. For the West Coast and the Central Valley of California, the enriched $\mathrm{NH}_{4}^{+}$mostly exists in the form of $\mathrm{NH}_{4} \mathrm{NO}_{3}$, as the sulfate concentration is low in this region for both periods. Figure $3 b$ and $d$ presents the spatial distribution of the difference in $\mathrm{NH}_{4}^{+}$concentration between the $\gamma=10^{-3}$ case and the base case, which is highly correlated with the $\mathrm{NH}_{3}$ variation map (Fig. 1). The reduction in $\mathrm{NH}_{3}$ due to the $\mathrm{SOA}$ uptake directly impacts the available $\mathrm{NH}_{3}$ that could be condensed into the particle phase and reduces the $\mathrm{NH}_{4}^{+}$concentration consequently. The spatial distribution of differences between the base case and the $\gamma=10^{-4}$ and $\gamma=10^{-5}$ cases is similar to the $\gamma=10^{-3}$ only with different scales, as shown in Fig. S17.

The concentration of $\mathrm{NO}_{3}^{-}$also changes as a result of adding the $\mathrm{NH}_{3}$ conversion into NOCs. Figure S18 shows the variation in daily-spatially averaged $\mathrm{NO}_{3}^{-}$concentration under different scenarios for both the winter and summer. Overall, adding the $\mathrm{NH}_{3}$ uptake mechanism leads to a decrease in $\mathrm{NO}_{3}^{-}$concentrations for both periods. Similar to $\mathrm{NH}_{4}^{+}$, the impact is more significant for the summer than the winter. The average reductions for the winter are $0.2 \%$ for $\gamma=10^{-5}, 1.9 \%$ for $\gamma=10^{-4}$, and $10.9 \%$ for $\gamma=10^{-3}$. For the summer, the average reductions are $1.9 \%$ for $\gamma=10^{-5}$, $10.6 \%$ for $\gamma=10^{-4}$, and $24.3 \%$ for $\gamma=10^{-3}$. Such varia- tions are similar to those of $\mathrm{NH}_{4}^{+}$, where the $\gamma=10^{-5}$ case in the summer has similar reductions to the $\gamma=10^{-4}$ case in the winter. And the magnitude of the difference is also close to the difference in $\mathrm{NH}_{4}^{+}$, indicating that almost all the $\mathrm{NH}_{4}^{+}$ reduction is from $\mathrm{NH}_{4} \mathrm{NO}_{3}$.

The spatial distributions of the $\mathrm{NO}_{3}^{-}$variation due to the addition of the $\mathrm{NH}_{3}$ uptake mechanism $\left(\gamma=10^{-3}\right)$ are presented in Fig. $4 \mathrm{~b}$ and $\mathrm{d}$ for the winter and summer. By comparing with the base cases (see Fig. 4a and c), it is clear that most of the $\mathrm{NO}_{3}^{-}$reduction occurs over regions with high $\mathrm{NO}_{3}^{-}$concentration, such as the Central Valley of California, the South Coast Air Basin of California, and vast regions over the mid-east US. One exception is the high $\mathrm{NO}_{3}^{-}$region over Canada on the north edge of Montana and North Dakota during the winter. Neither $\mathrm{NH}_{4}^{+}$concentration nor $\mathrm{NO}_{3}^{-}$concentration changes much, mostly because the SOA concentration is extremely low for that region (see Fig. 6a), so almost no $\mathrm{NH}_{3}$ is lost due to the SOA uptake. The same occurs in south Florida during the summer. The spatial distribution of differences between the base case and the $\gamma=10^{-4}$ and $\gamma=10^{-5}$ cases is similar to the $\gamma=10^{-3}$ only with different scales (shown in Fig. S19).

\subsubsection{Impact on organic PM}

Figure $6 \mathrm{a}$ and $\mathrm{c}$ show the time-averaged spatial distribution of SOA for the winter and summer base cases. For both seasons, high SOA concentrations are found over the southeastern US due to high vegetation coverage in this region, while hotspots in the northwestern region are caused by widespread fire events. The averaged SOA concentration is more than 3 times higher in the summer case $\left(9.25 \mu \mathrm{g} \mathrm{m}^{-3}\right)$ than in the winter $\left(2.72 \mu \mathrm{g} \mathrm{m}^{-3}\right)$, largely due to the much higher biogenic SOA (BIOSOA) concentrations $\left(4.43 \mu \mathrm{g} \mathrm{m}^{-3}\right.$ summer vs. $0.22 \mu \mathrm{g} \mathrm{m}^{-3}$ winter) resulting from elevated biogenic emissions in the warm season. 

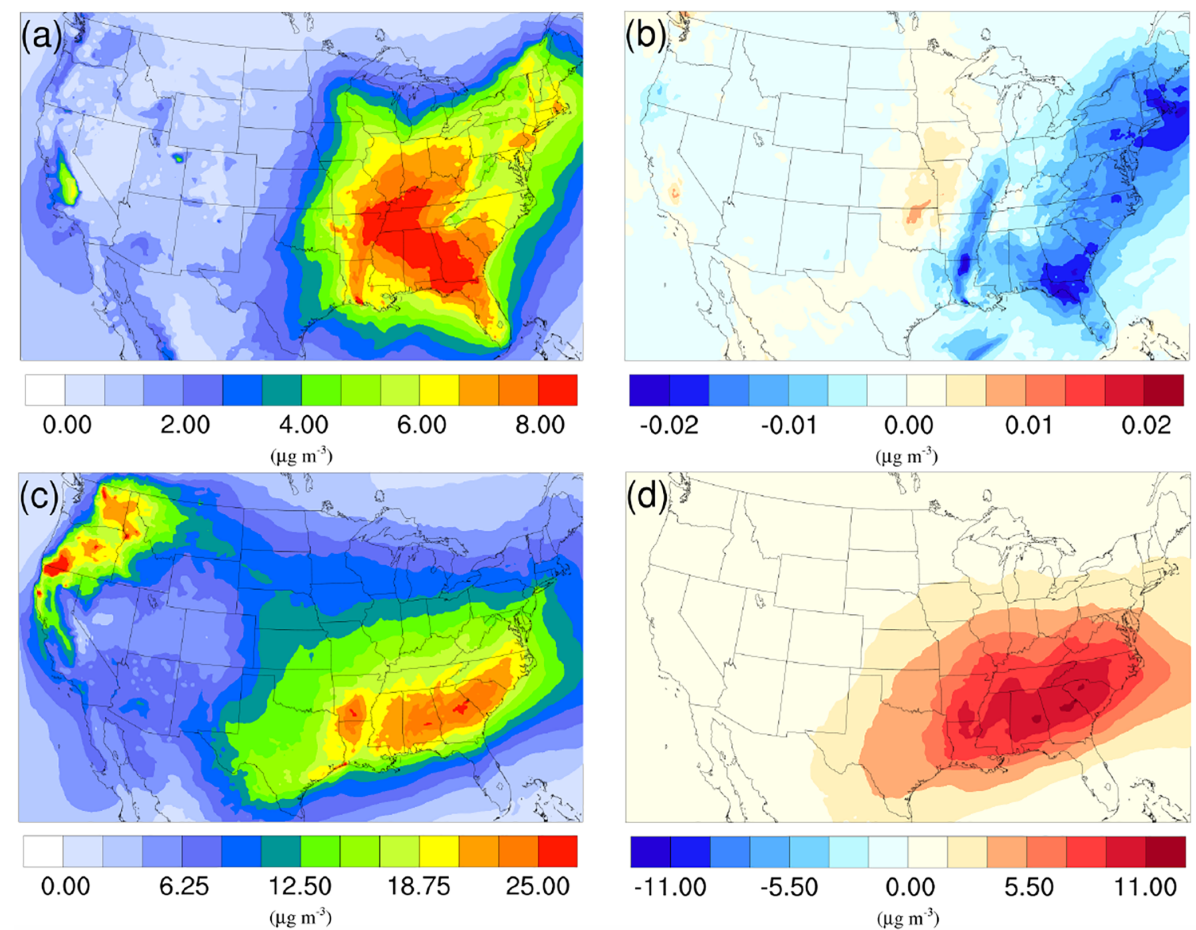

Figure 6. Spatial distribution of time-averaged SOA concentrations in the base case for (a) winter and (c) summer. Spatial distribution of the difference in time-averaged SOA concentrations between the $\gamma=10^{-3}$ case and the base case for (b) winter and (d) summer. Positive values represent increases in concentration with respect to the base case, and negative values represent decreases in concentration with respect to the base case.

As mentioned in Sect. 2, the $\mathrm{NH}_{3}$ uptake parametrization used in this study does not directly add mass to SOA because the original SOA carbonyl and the NOCs they convert into have similar molecular weight. However, significant changes in SOA concentration are observed after implementing the $\mathrm{NH}_{3}$ uptake mechanism, which is indirectly caused by the changes in particle acidity (see below). As demonstrated in Fig. $6 \mathrm{~b}$ and $\mathrm{d}$, implementing the $\mathrm{NH}_{3}$ uptake mechanism has a significant impact on the SOA concentrations during the summer, but has almost no impact on SOA for the winter. Almost the entire increase in SOA concentrations in the summer is due to the mass change in biogenic SOA (see Figs. 7a and $6 \mathrm{~d}$; their average concentrations for the base case are in Fig. S20). Further investigation reveals that the majority of the increase $(\sim 80 \%)$ is caused by the nonvolatile AISO3 species (Fig. 7b), which is the isoprene epoxydiols (IEPOX)derived SOA through the acid-catalyzed ring-opening reactions (Pye et al., 2013). This increase in AISO3 is caused by the increase in aerosol aqueous-phase acidity due to the reduction in $\mathrm{NH}_{4}^{+}$after adding the $\mathrm{NH}_{3}$ conversion into NOCs. This increase in particle acidity corresponds well with the sensitivity study between $\mathrm{NH}_{3}, \mathrm{SO}_{4}^{2-}$, and particle $\mathrm{pH}$ presented in Fig. 2 of Weber et al. (2016), where particle pH is found to be more sensitive to $\mathrm{NH}_{3}$ concentrations than to $\mathrm{SO}_{4}^{2-}$ concentrations. Figure 7c shows a large drop in $\mathrm{pH}$ value $(\sim 0.9-2.3)$ ( $\mathrm{pH}$ changes for other scenarios are shown in Fig. S21) in the southeast region where the increase in the AISO3 is most significant and there is a simultaneous decrease in IEPOX concentrations (Fig. 7d). The largest $\mathrm{pH}$ variation appears over the northwest region. However, there is no observable impact on SOA concentrations due to the extremely low concentration of both isoprene and IEPOX (see Fig. 7e and $\mathrm{f}$ ) in this area. Moreover, the reduction in $\mathrm{NH}_{4}^{+}$concentrations also increases the ratio of $\mathrm{SO}_{4}^{2-} / \mathrm{HSO}_{4}^{-}$, where $\mathrm{SO}_{4}^{2-}$ can act as a nucleophile and promote the IEPOX uptake process. This also contributes to the increase in AISO3 in the $\gamma=10^{-3}$ case.

Figure 8 shows the time evolution of daily-spatially averaged $\mathrm{H}^{+}$, IEPOX, and AISO3 for both the winter and summer. Although the average $\mathrm{H}^{+}$concentration in the base case is similar between two periods, the variation is much smaller for the winter largely due to the lower $\mathrm{SO}_{4}^{2-}$ concentrations in the winter which restrain the acidity variation level. Additionally, lower SOA concentrations in winter also reduce the magnitude of $\mathrm{NH}_{4}^{+}$variation. As a result, addition of the $\mathrm{NH}_{3}$ uptake mechanism does not have a large impact on the AISO3 concentration for most of the simulation (except for the last several days). On the contrary, the summer shows a significant increase in $\mathrm{H}^{+}$concentrations as the $\mathrm{NH}_{3}$ uptake coefficient increases, while the concentration of IEPOX decreases. And the increase in AISO3 concentration is remarkable, with more than 10 times the growth on average be- 

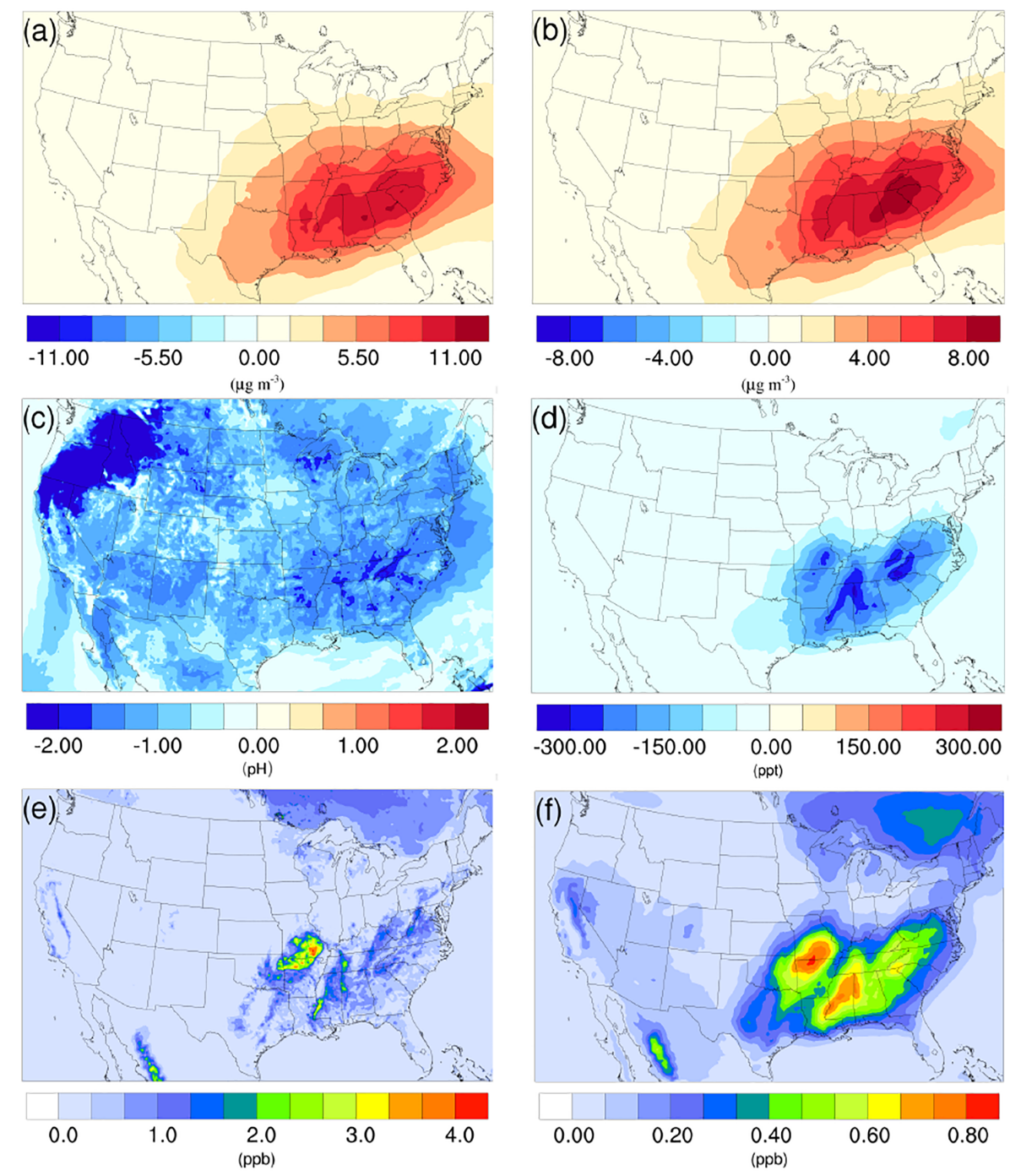

Figure 7. Spatial distribution of the difference in time-averaged (a) biogenic SOA concentrations, (b) isoprene epoxydiols (IEPOX)-derived SOA concentrations, $(\mathbf{c})$ particle acidity $(\mathrm{pH})$, and $(\mathbf{d})$ isoprene epoxydiols concentrations between the $\gamma=10^{-3}$ case and the base case during the summer. Spatial distribution of time-averaged (e) isoprene, and (f) isoprene epoxydiols concentration in the base case during the summer.

tween the $\gamma=10^{-3}$ case $\left(1875.2 \mathrm{ng} \mathrm{m}^{-3}\right)$ and the base case $\left(181.75 \mathrm{ng} \mathrm{m}^{-3}\right)$. The amount of growth on AISO3 seems linear with different values of the $\mathrm{NH}_{3}$ uptake coefficient $\left(\gamma=10^{-5}: 16.2 \% ; \gamma=10^{-4}: 171.9 \% ; \gamma=10^{-3}: 931.6 \%\right)$.

In addition to the isoprene epoxydiols pathway, other biogenic SOA species contribute the rest of the SOA changes ( $\sim 20 \%$ ), including other SOA species derived from isoprene (AISO1 and AISO2), from monoterpenes (ATRP1 and ATRP2), from sesquiterpenes (ASQT), and AOLGB, which represents the aged nonvolatile SOA origin from AISO1, AISO2, ATRP1, ATRP2, and ASQT. The common point with those SOAs (AISO1, AISO2, ATRP1, ATRP2, and ASQT) is that they all have a pathway to be formed through the oxidation between gas-phase $\mathrm{NO}_{3}$ radicals and their gas precursors. One possible explanation could be that the addition of
$\mathrm{NH}_{3}$ uptake leads to an increase in gas-phase $\mathrm{HNO}_{3}$, which could shift the reaction balances between $\mathrm{NO}_{3}$ and $\mathrm{HNO}_{3}$ and leave more $\mathrm{NO}_{3}$ available for SOA oxidation.

\subsubsection{Impact on total PM}

Figure S22 presents the time evolution of daily-averaged concentrations of $\mathrm{PM}_{2.5}$ and $\mathrm{PM}_{10}$ in different scenarios during both periods. First, both the pattern and level of impact caused by the $\mathrm{NH}_{3}$ uptake mechanism is similar for $\mathrm{PM}_{2.5}$ and $\mathrm{PM}_{10}$, which indicates that most of the mass change due to this process occurs on fine particles. Secondly, the level of impact on both $\mathrm{PM}_{2.5}$ and $\mathrm{PM}_{10}$ is much more significant over the summer than the winter, which is consistent with previous analysis of individual species. Third, opposite 

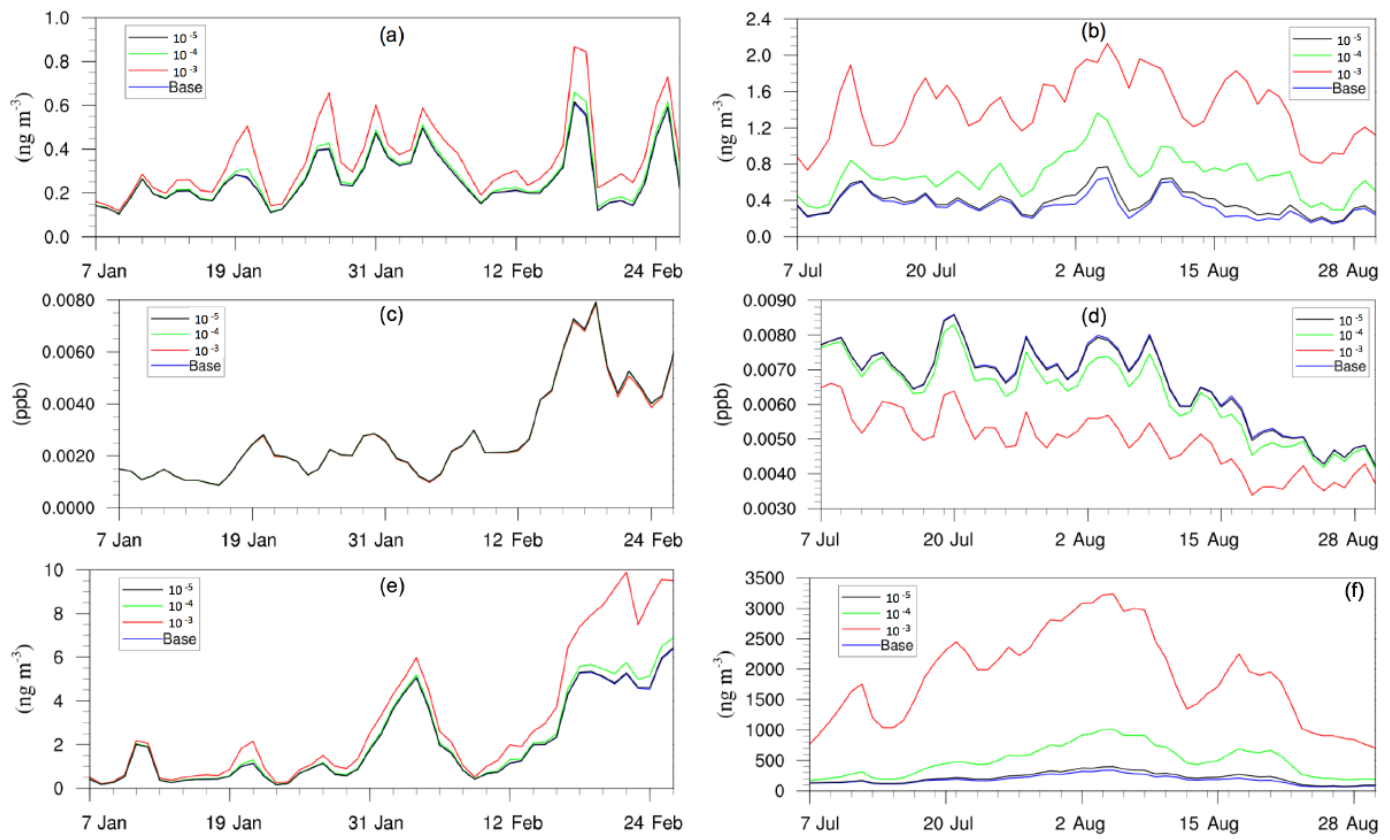

Figure 8. Daily, spatially averaged concentrations of (a) particle-phase $\mathrm{H}^{+}$in winter, (b) particle-phase $\mathrm{H}^{+}$in summer, (c) isoprene epoxydiols in winter, (d) isoprene epoxydiols in summer, (e) isoprene-epoxydiol-derived SOA in winter, and (f) isoprene-epoxydiol-derived SOA in summer.

impact patterns are found between the winter and summer. The inclusion of the $\mathrm{NH}_{3}$ uptake mechanism leads to a decrease in the total PM mass for the winter, which is caused by the reduction of inorganic $\mathrm{NH}_{4}^{+}$and $\mathrm{NO}_{3}^{-}$due to the decrease in the $\mathrm{NH}_{3}$ concentration, as detailed in Sect. 3.2.2. On the contrary, PM concentrations during the summer increase after adding the $\mathrm{NH}_{3}$ uptake mechanism. Although the concentration of inorganic species still decreases during the summer, the increase in biogenic SOA concentration, as detailed in Sect. 3.2.3, outpaces the decrease caused by inorganic species and leads to an overall increase in total PM mass for the summer. For the winter, the average $\mathrm{PM}_{2.5}$ concentration reduction is $0.07 \%$ for the $\gamma=10^{-5}$ case, $0.59 \%$ for the $\gamma=10^{-4}$ case, and $3.39 \%$ for the $\gamma=10^{-3}$ case. For the summer, the average $\mathrm{PM}_{2.5}$ concentration increase is $0.14 \%$ for the $\gamma=10^{-5}$ case, $2.05 \%$ for the $\gamma=10^{-4}$ case, and $12.38 \%$ for the $\gamma=10^{-3}$ case.

The spatial distribution of time-averaged $\mathrm{PM}_{2.5}$ concentration for the winter and summer is presented in Fig. 9a and $\mathrm{c}$, respectively. Most of the high $\mathrm{PM}_{2.5}$ concentration happens over the mid-east US during the winter, with additional hotspots over the Central Valley of California, resulting in an overall average of $7.47 \mu \mathrm{g} \mathrm{m}^{-3} . \mathrm{PM}_{2.5}$ concentrations are highly correlated with the population density map of the US, indicating a dominant anthropogenic origin. The relatively low fraction of biogenic SOA in winter also supports this point (Fig. 10a). The model predicts a much higher $\mathrm{PM}_{2.5}$ concentration for the summer, with an average concentration of $16.17 \mu \mathrm{g} \mathrm{m}^{-3}$. The hotspots ob- served over the northwest of the country and coastal area over southeast Texas are caused by wild fire events. In general, high $\mathrm{PM}_{2.5}$ concentrations are predicted over the southeast of the US, where high fractions of biogenic SOA are presented in Fig. 10b. This could be a result of both high average temperatures during the summer and high vegetation density in that region. Figure $9 \mathrm{~b}$ shows the variation in $\mathrm{PM}_{2.5}$ concentrations between the $\gamma=10^{-3}$ case and the base case for the winter. An overall reduction can be observed from the map, with the highest reduction around the Central Valley of California and a smaller reduction over the vast mid-east region. This is mostly caused by the decrease in $\mathrm{NH}_{4} \mathrm{NO}_{3}$ due to the reduction of gas-phase $\mathrm{NH}_{3}$ concentrations as discussed in Sect. 3.2.2. For the summer, although the decrease still appears over the northwest of the country, the prominent feature becomes a significant increase in $\mathrm{PM}_{2.5}$ concentrations over the southeast region. This is due to the increase in biogenic SOA resulting from the enhanced acid-catalyzed ring-opening reactions as detailed in Sect. 3.2.3.

\section{Conclusions}

In this study, the potential air quality impacts of the heterogeneous uptake of $\mathrm{NH}_{3}$ by $\mathrm{SOA}$ accompanied by formation of NOCs are investigated with the CMAQ model. Simulations over the continental US are performed for the winter and summer seasons of 2011 with a range of $\mathrm{NH}_{3}$ uptake coefficients reported in the literature. First, the simulation results for the two base case simulations are compared with obser- 

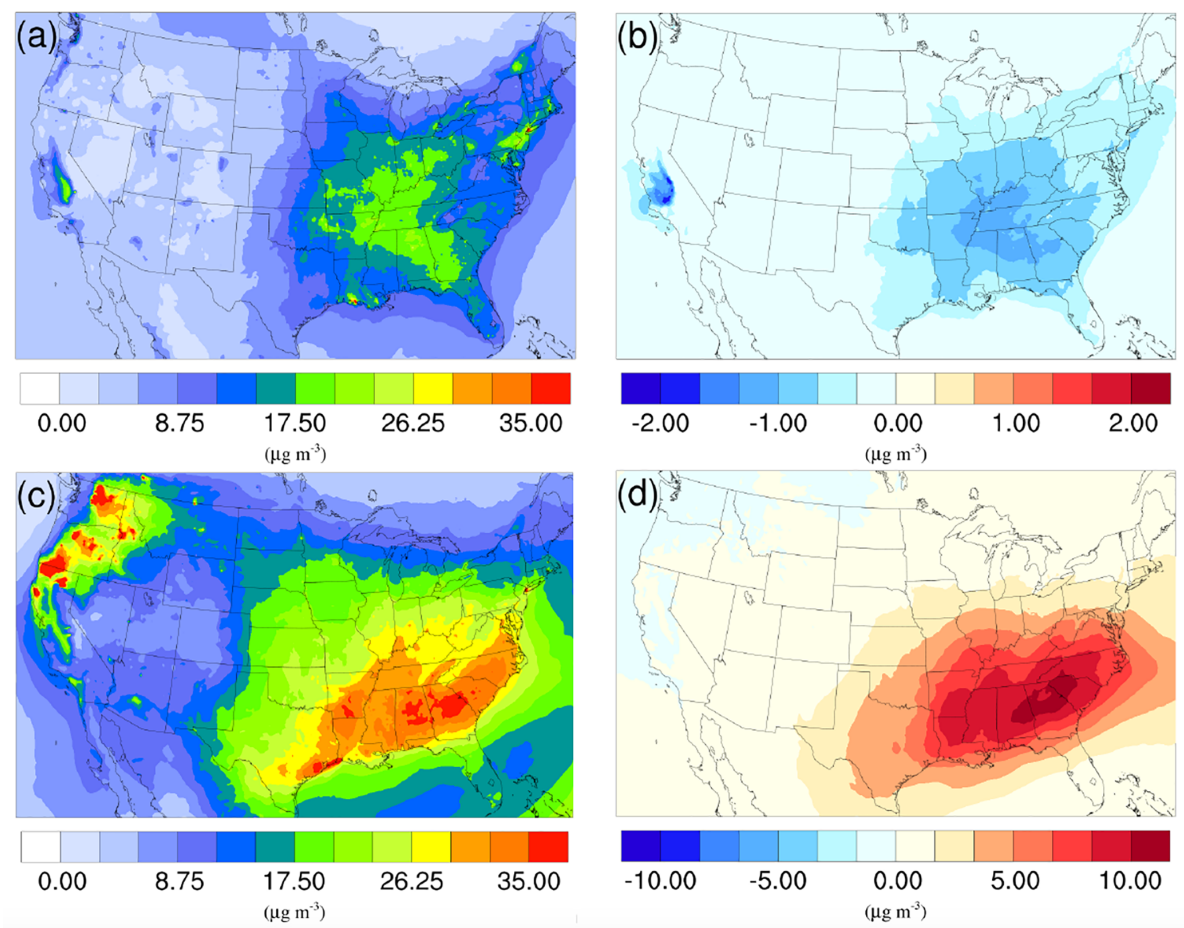

Figure 9. Spatial distribution of time-averaged $\mathrm{PM}_{2.5}$ concentrations in the base case for (a) winter and (c) summer. Spatial distribution of the difference in time-averaged $\mathrm{PM}_{2.5}$ concentrations between the $\gamma=10^{-3}$ case and the base case for (b) winter and (d) summer. Positive values represent increases in concentration with respect to the base case, and negative values represent decreases in concentration with respect to the base case.
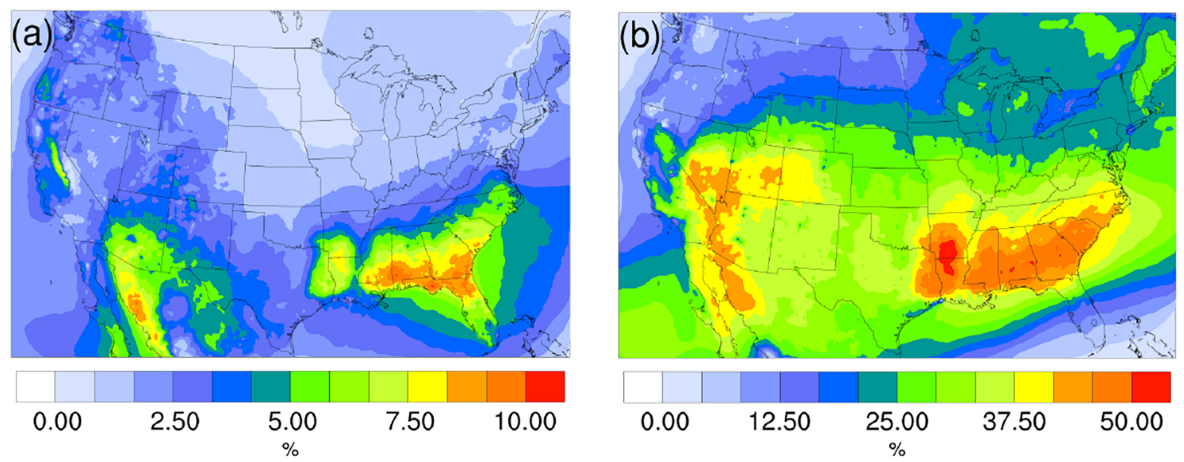

Figure 10. Spatial distribution of time-averaged biogenic SOA fraction of total $\mathrm{PM}_{2.5}$ for (a) the winter and (b) summer.

vation data from different monitoring networks, and statistics show an overall good model performance for most of the criteria. The inclusion of the SOA-based $\mathrm{NH}_{3}$ conversion into NOCs has a significant impact on the statistics of $\mathrm{NH}_{3}, \mathrm{NH}_{4}^{+}$, and $\mathrm{NO}_{3}^{-}$, but does not affect $\mathrm{O}_{3}$ and $\mathrm{SO}_{4}^{2-}$. The overestimation of $\mathrm{NH}_{3}$ and $\mathrm{NH}_{4}^{+}$for the summer is reduced by this new mechanism. Moreover, the prediction of $\mathrm{NO}_{3}^{-}$is improved by this mechanism, given that the overestimation of $\mathrm{NO}_{3}^{-}$ concentration gradually subsides as the uptake coefficient increases.
The comparison between different uptake coefficient scenarios and the base case allows a more detailed understanding of the impact of this mechanism on both gas-phase and particle-phase species. Simulation results indicate a significant reduction in gas-phase $\mathrm{NH}_{3}$ due to conversion of $\mathrm{NH}_{3}$ into NOCs, and such reduction increases dramatically as the uptake coefficient increases. The highest spatially averaged reduction in gas-phase $\mathrm{NH}_{3}$ is $31.3 \%$ in the winter and $67.0 \%$ in the summer. This analysis is based on a range of uptake coefficients that span those reported in the literature. However, the actual value for each individual SOA could be lower or higher than the uniform uptake coefficient used in 
this study, although the magnitude of the impact still indicates the importance of including this process in air quality models. The seasonal differences are obvious as the impact is much more significant in the summer than in the winter, due to much higher $\mathrm{NH}_{3}$ and SOA concentration in the summer. The concentration of gas-phase $\mathrm{HNO}_{3}$ is also impacted by this new mechanism. As the $\mathrm{NH}_{3}$ concentration drops because it is being converted into NOCs, less $\mathrm{HNO}_{3}$ is neutralized by $\mathrm{NH}_{3}$, resulting in an overall increase in $\mathrm{HNO}_{3}$ concentration. Such increases can be as high as $8.5 \%$ in the winter and $19.6 \%$ in the summer for the largest uptake coefficient. Geographically, the biggest reduction in $\mathrm{NH}_{3}$ happens in the Central Valley of California during both seasons, the same location as the biggest increase in $\mathrm{HNO}_{3}$ in the winter. While for the summer, $\mathrm{HNO}_{3}$ increases more dramatically over the South Coast Air Basin of California and the northeast region of the country.

PM concentrations are found to decrease during the winter period, largely due to the reduction in ammonium nitrate formation caused by the decrease in gas-phase ammonia. The largest uptake scenario $\left(\gamma=10^{-3}\right)$ leads to a $13.2 \%$ reduction of $\mathrm{NH}_{4}^{+}, 10.6 \%$ reduction of $\mathrm{NO}_{3}^{-}$, and $3.4 \%$ reduction of $\mathrm{PM}_{2.5}$ in the winter. The most significant reduction also happens over the Central Valley region of California with a highest $\mathrm{PM}_{2.5}$ drop of $2.0 \mu \mathrm{g} \mathrm{m}^{-3}$. On the other hand, PM concentrations are found to increase during the summer due to the increase in biogenic SOA production resulting from the enhanced acid-catalyzed ring-opening reactions. Although the reduction in ammonium nitrate is even larger in magnitude during the summer $\left(28.2 \%\right.$ reduction in $\mathrm{NH}_{4}^{+}, 24.3 \%$ reduction in $\mathrm{NO}_{3}^{-}$) than the winter, the dramatic increase in biogenic SOA outpaced the decrease caused by ammonium nitrate to result in an overall increase in total PM (12.4\% increase in $\mathrm{PM}_{2.5}$ ). Most of the biogenic SOA increases occur over the southeast region of the US, where high vegetation density is located. The average increase in biogenic SOA is $0.9 \%$ for $\gamma=10^{-5}, 9.2 \%$ for $\gamma=10^{-4}$, and $49.0 \%$ for $\gamma=10^{-3}$. For the species (AISO3) that is responsible for most of the increase, the $\gamma=10^{-3}$ case leads to a 10 -fold increase in concentration compared to the base case.

Results of this study show that the chemical uptake of $\mathrm{NH}_{3}$ by SOA can have a significant impact on the model-predicted concentration of important atmospheric pollutants, including $\mathrm{NH}_{3}, \mathrm{HNO}_{3}, \mathrm{NH}_{4}^{+}, \mathrm{NO}_{3}^{-}$, and biogenic SOA. The impact on the total PM has a distinct pattern on different seasons. Future laboratory studies should be conducted to identify the nature of the chemical reaction between $\mathrm{NH}_{3}$ and SOA species to provide more accurate model representation of the uptake process. Furthermore, better knowledge about basicity of NOCs is needed to verify whether they can neutralize inorganic acids. For example, single particle measurements conducted by Neuman et al. (2003) showed that organic aerosols also contributed to increases in fine-particle mass in regions with high $\mathrm{NH}_{3}$ emissions rates, suggesting that $\mathrm{NH}_{3}$ uptake can increase organic aerosol mass concentrations directly.
Current air quality models only include one pathway for the acid-catalyzed SOA generation (based on the high $\mathrm{NO}_{x}$ case in the study of Pye et al., 2013), and a more detailed representation of other acid-catalyzed pathways could lead to an even larger impact on the SOA concentration.

Code and data availability. Simulation result data sets are available upon request as they are too big to upload online (812 GB). The original CMAQ (version 5.2) code for the base case simulation is available on the CMAS website: https://www.cmascenter.org/ cmaq/. The updated CMAQ code including the $\mathrm{NH}_{3}$ uptake mechanism is available under the following link: http://albeniz.eng.uci. edu/software/CMAQv5.2_withNH3Uptake.zip. The CMAQ model has a GNU General Public License. The user can redistribute the model and/or modify the model under the terms of the GNU General Public License as published by the Free Software Foundation.

Supplement. The supplement related to this article is available online at: https://doi.org/10.5194/acp-18-3641-2018-supplement.

Competing interests. The authors declare that they have no conflict of interest.

Acknowledgements. This publication was developed under Assistance Agreement no. EPA 83588101 awarded by the US Environmental Protection Agency to the Regents of the University of California. It has not been formally reviewed by the EPA. The views expressed in this document are solely those of the authors and do not necessarily reflect those of the agency. The EPA does not endorse any products or commercial services mentioned in this publication. We also express our gratitude for UCI HPC assistance and especially to Harry Mangalam and Garr Updegraff for their generous support, as well as to the UCI Research Computing group especially Allen Schiano and Dana Roode.

Edited by: Kostas Tsigaridis

Reviewed by: two anonymous referees

\section{References}

Adams, L.: Mechanism for cb6r3_ae6_aq uses the following species, https://github.com/USEPA/CMAQ/blob/5.2/DOCS/ User_Manual/Appendix_A/cb6r3_ae6_aq/CB6_species_table. md, last access: 15 December 2017.

Amann, M., Klimont, Z., and Wagner, F.: Regional and global emissions of air pollutants: recent trends and future scenarios, Ann. Rev. Environ. Resour., 38, 31-55, 2013.

Aneja, V. P., Chauhan, J., and Walker, J.: Characterization of atmospheric ammonia emissions from swine waste storage and treatment lagoons, J. Geophys. Res.-Atmos., 105, 11535-11545, 2000.

Appel, K. W., Bhave, P. V., Gilliland, A. B., Sarwar, G., and Roselle, S. J.: Evaluation of the community multiscale air qual- 
ity (CMAQ) model version 4.5: sensitivities impacting model performance; part II - particulate matter, Atmos. Environ., 42, 6057-6066, 2008.

Baek, B. H. and Aneja, V. P.: Measurement and analysis of the relationship between ammonia, acid gases, and fine particles in Eastern North Carolina, J. Air Waste Manage. Assoc., 54, 623-633, 2004.

Behera, S. N. and Sharma, M.: Investigating the potential role of ammonia in ion chemistry of fine particulate matter formation for an urban environment, Sci. Total Environ., 408, 3569-3575, 2010.

Behera, S. N., Sharma, M., Aneja, V. P., and Balasubramanian, R.: Ammonia in the atmosphere: a review on emission sources, atmospheric chemistry and deposition on terrestrial bodies, Environ. Sci. Pollut. Res., 20, 8092-8131, 2013.

Binkowski, F. S. and Roselle, S. J.: Models-3 Community Multiscale Air Quality (CMAQ) model aerosol component 1. Model description, J. Geophys. Res.-Atmos., 108, 4183, https://doi.org/10.1029/2001JD001409, 2003.

Boylan, J. W. and Russell, A.G.: PM and light extinction model performance metrics, goals, and criteria for three-dimensional air quality models, Atmos. Environ., 40, 4946-4959, 2006.

Byun, D. and Schere, K. L.: Review of the governing equations, computational algorithms, and other components of the Models3 Community Multiscale Air Quality (CMAQ) modeling system, Appl. Mech. Rev., 59, 51-77, 2006.

Eder, B. and Yu, S.: A performance evaluation of the 2004 release of Models-3 CMAQ, Atmos. Environ., 40, 4811-4824, 2006.

Erisman, J. W., Sutton, M. A., Galloway, J., Klimont, Z., and Winiwarter, W.: How a century of ammonia synthesis changed the world, Nat. Geosci., 1, 636-639, 2008.

Friedl, M. A., Sulla-Menashe, D., Tan, B., Schneider, A., Ramankutty, N., Sibley, A., and Huang, X.: MODIS Collection 5 global land cover: Algorithm refinements and characterization of new datasets, Remote Sens. Environ., 114, 168-182, 2010.

Galloway, J. N., Townsend, A. R., Erisman, J. W., Bekunda, M., Cai, Z., Freney, J. R., Martinelli, L. A., Seitzinger, S. P., and Sutton, M. A.: Transformation of the nitrogen cycle: recent trends, questions, and potential solutions, Science, 320, 889-892, 2008.

Hong, S.-Y., Dudhia, J., and Chen, S.-H.: A revised approach to ice microphysical processes for the bulk parameterization of clouds and precipitation, Mon. Weather Rev., 132, 103-120, 2004.

Hong, S.-Y., Noh, Y., and Dudhia, J.: A new vertical diffusion package with an explicit treatment of entrainment processes, Mon. Weather Rev., 134, 2318-2341, 2006.

Horne, J. R., Zhu, S., Montoya, J., Hinks, M. L., Nizkorodov, S. A., and Dabdub, D.: Reactive Uptake of Ammonia by Secondary Organic Aerosols: Implications for Air Quality, Atmos. Emviron., in review, 2018.

Horowitz, L. W., Walters, S., Mauzerall, D. L., Emmons, L. K., Rasch, P. J., Granier, C., Tie, X., Lamarque, J. F., Schultz, M. G., Tyndall, G. S., Orlando, J. J., and Brasseur, G. P.: A global simulation of tropospheric ozone and related tracers: Description and evaluation of MOZART, version 2, J. Geophys. Res.-Atmos., 108, 4784, https://doi.org/10.1029/2002JD002853, 2003.

Jovan, S. and McCune, B.: Air-quality bioindication in the greater central valley of calfornia, with epophytic macrolichen communities, Ecol. Appl., 15, 1712-1726, 2005.
Kain, J. S.: The Kain-Fritsch convective parameterization: an update, J. Appl. Meteorol., 43, 170-181, 2004.

Krauter, C., Goorahoo, D., Potter, C., and Klooster, S.: Ammonia emissions and fertilizer applications in California's Central Valley, Emission Inventories - Partnering for the Future, 11, 15-18, 2002.

Laskin, A., Laskin, J., and Nizkorodov, S. A.: Chemistry of atmospheric brown carbon, Chem. Rev., 115, 4335-4382, 2015.

Laskin, J., Laskin, A., Nizkorodov, S. A., Roach, P., Eckert, P., Gilles, M. K., Wang, B., Lee, H. J., and Hu, Q.: Molecular selectivity of brown carbon chromophores, Environ. Sci. Technol., 48, 12047-12055, 2014.

Lee, L., Wooldridge, P. J., Gilman, J. B., Warneke, C., de Gouw, J., and Cohen, R. C.: Low temperatures enhance organic nitrate formation: evidence from observations in the 2012 Uintah Basin Winter Ozone Study, Atmos. Chem. Phys., 14, 12441-12454, https://doi.org/10.5194/acp-14-12441-2014, 2014.

Lelieveld, J., Evans, J., Fnais, M., Giannadaki, D., and Pozzer, A.: The contribution of outdoor air pollution sources to premature mortality on a global scale, Nature, 525, 367-371, 2015.

Lin, Y.-H., Knipping, E. M., Edgerton, E. S., Shaw, S. L., and Surratt, J. D.: Investigating the influences of $\mathrm{SO}_{2}$ and $\mathrm{NH}_{3}$ levels on isoprene-derived secondary organic aerosol formation using conditional sampling approaches, Atmos. Chem. Phys., 13, 84578470, https://doi.org/10.5194/acp-13-8457-2013, 2013.

Liu, Y., Liggio, J., Staebler, R., and Li, S.-M.: Reactive uptake of ammonia to secondary organic aerosols: kinetics of organonitrogen formation, Atmos. Chem. Phys., 15, 1356913584, https://doi.org/10.5194/acp-15-13569-2015, 2015.

Malm, W. C., Schichtel, B. A., Pitchford, M. L., Ashbaugh, L. L., and Eldred, R. A.: Spatial and monthly trends in speciated fine particle concentration in the United States, J. Geophys. Res.Atmos., 109, D03306, https://doi.org/10.1029/2003JD003739, 2004.

McCulloch, R. B., Few, G. S., Murray, G. C., and Aneja, V. P.: Analysis of ammonia, ammonium aerosols and acid gases in the atmosphere at a commercial hog farm in eastern North Carolina, USA, Environ. Pollut., 102, 263-268, 1998.

Na, K., Song, C., Switzer, C., and Cocker, D. R.: Effect of ammonia on secondary organic aerosol formation from $\alpha$-pinene ozonolysis in dry and humid conditions, Environ. Sci. Technol., 41, 6096-6102, 2007.

NADP: Ambient Ammonia Monitoring Network (AMoN), http: //nadp.sws.uiuc.edu/AMoN/AMoNFactSheet.pdf (last access: 25 September 2017), 2014.

NCEP: National Weather Service, NCEP FNL, Operational Model Global Tropospheric Analyses, NOAA, US Department of Commerce, continuing from July 1999, Research Data Archive at the National Center for Atmospheric Research, Computational and Information Systems Laboratory, https://doi.org/10.5065/D6M043C6, 2000.

Neuman, J. A., Nowak, J. B., Brock, C. A., Trainer, M., Fehsenfeld, F. C., Holloway, J. S., Hübler, G., Hudson, P. K., Murphy, D. M., Nicks, D. K., and Orsini, D.: Variability in ammonium nitrate formation and nitric acid depletion with altitude and location over California, J. Geophys. Res.-Atmos., 108, 4557, https://doi.org/10.1029/2003JD003616, 2003.

Nowak, J., Neuman, J., Bahreini, R., Middlebrook, A., Holloway, J., McKeen, S., Parrish, D., Ryerson, T., and Trainer, M.: Am- 
monia sources in the California South Coast Air Basin and their impact on ammonium nitrate formation, Geophys. Res. Lett., 39, L07804, https://doi.org/10.1029/2012GL051197, 2012.

Otte, T. L. and Pleim, J. E.: The Meteorology-Chemistry Interface Processor (MCIP) for the CMAQ modeling system: updates through MCIPv3.4.1, Geosci. Model Dev., 3, 243-256, https://doi.org/10.5194/gmd-3-243-2010, 2010.

Park, R. S., Lee, S., Shin, S.-K., and Song, C. H.: Contribution of ammonium nitrate to aerosol optical depth and direct radiative forcing by aerosols over East Asia, Atmos. Chem. Phys., 14, 2185-2201, https://doi.org/10.5194/acp-14-2185-2014, 2014.

Pierce, T. E. and Waldruff, P. S.: PC-BEIS: a personal computer version of the biogenic emissions inventory system, J. Air Waste Manage. Assoc., 41, 937-941, 1991.

Pinder, R. W., Strader, R., Davidson, C. I., and Adams, P. J.: A temporally and spatially resolved ammonia emission inventory for dairy cows in the United States, Atmos. Environ., 38, 3747-3756, 2004.

Pinder, R. W., Adams, P. J., Pandis, S. N., and Gilliland, A. B.: Temporally resolved ammonia emission inventories: Current estimates, evaluation tools, and measurement needs, J. Geophys. Res.-Atmos., 111, D16310, https://doi.org/10.1029/2005JD006603, 2006.

Pope III, C. A., Burnett, R. T., Thun, M. J., Calle, E. E., Krewski, D., Ito, K., and Thurston, G. D.: Lung cancer, cardiopulmonary mortality, and long-term exposure to fine particulate air pollution, $\mathrm{J}$. Am. Med. Assoc., 287, 1132-1141, 2002.

Pye, H. O., Pinder, R. W., Piletic, I. R., Xie, Y., Capps, S. L., Lin, Y. H., Surratt, J. D., Zhang, Z., Gold, A., Luecken, D. J., and Hutzell, W. T. : Epoxide pathways improve model predictions of isoprene markers and reveal key role of acidity in aerosol formation, Environ. Sci. Technol., 47, 11056-11064, 2013.

Pye, H. O.: CMAQv5.1 SOA Update, https://www. airqualitymodeling.org/index.php/CMAQv5.1_SOA_Update (last access: 25 September 2017), 2016.

Russell, A. and Dennis, R.: NARSTO critical review of photochemical models and modeling, Atmos. Environ., 34, 2283-2324, 2000.

Seinfeld, J. H. and Pandis, S. N.: Atmospheric chemistry and physics: from air pollution to climate change, John Wiley \& Sons, New York, 2016.

Sheppard, L. J., Leith, I. D., Mizunuma, T., Neil Cape, J., Crossley, A., Leeson, S., Sutton, M. A., Dijk, N., and Fowler, D.: Dry deposition of ammonia gas drives species change faster than wet deposition of ammonium ions: evidence from a long-term field manipulation, Global Change Biol., 17, 3589-3607, 2011.

Skamarock, W., Klemp, J., Dudhia, J., Gill, D., Barker, D., Duda, M., Huang, X., Wang, W., and Powers, J.: A description of the Advanced Research WRF Version 3, NCAR technical note, Mesoscale and Microscale Meteorology Division, National Center for Atmospheric Research, Boulder, Colorado, USA, 2008.
Sutton, M., Pitcairn, C. E., and Fowler, D.: The exchange of ammonia between the atmosphere and plant communities, Adv. Ecol. Res., 24, 301-393, 1993.

Updyke, K. M., Nguyen, T. B., and Nizkorodov, S. A.: Formation of brown carbon via reactions of ammonia with secondary organic aerosols from biogenic and anthropogenic precursors, Atmos. Environ., 63, 22-31, 2012.

US EPA: User's Guide to MOBILE6.1 and MOBILE6.2, Environmental Protection Agency, Ann Arbor, USA, 2003.

US EPA: Guidance on the use of models and other analyses for demonstrating attainment of air quality goals for ozone, $\mathrm{PM}_{2.5}$, and regional haze, US Environmental Protection Agency, Office of Air Quality Planning and Standards, Research Triangle Park, North Carolina, 2007.

US EPA: 2014 National Emissions Inventory (NEI) Technical Support Document (TSD), https://www.epa.gov/sites/ production/files/2016-12/documents/nei2014v1_tsd.pdf (last access: 12 July 2017), 2017a.

US EPA: SMOKE v4.5 User's Manual, https://www.cmascenter. org/smoke/documentation/4.5/manual_smokev45.pdf (last access: 12 July 2017), 2017b.

Vayenas, D. V., Takahama, S., Davidson, C. I., and Pandis, S. N.: Simulation of the thermodynamics and removal processes in the sulfate-ammonia-nitric acid system during winter: Implications for $\mathrm{PM}_{2.5}$ control strategies, J. Geophys. Res.-Atmos., 110 , D07S14, https://doi.org/10.1029/2004JD005038, 2005.

Wang, Y., Zhang, Q. Q., He, K., Zhang, Q., and Chai, L.: Sulfate-nitrate-ammonium aerosols over China: response to 2000-2015 emission changes of sulfur dioxide, nitrogen oxides, and ammonia, Atmos. Chem. Phys., 13, 2635-2652, https://doi.org/10.5194/acp-13-2635-2013, 2013.

Warner, J., Dickerson, R., Wei, Z., Strow, L., Wang, Y., and Liang, Q.: Increased atmospheric ammonia over the world's major agricultural areas detected from space, Geophys. Res. Lett., 44, 2875-2884, 2017.

Weber, R. J., Guo, H., Russell, A. G., and Nenes, A.: High aerosol acidity despite declining atmospheric sulfate concentrations over the past 15 years, Nat. Geosci., 9, 282-285, 2016.

West, J. J., Ansari, A. S., and Pandis, S. N.: Marginal PM25: nonlinear aerosol mass response to sulfate reductions in the Eastern United States, J. Air Waste Manage. Assoc., 49, 1415-1424, 1999.

Xu, L. and Penner, J. E.: Global simulations of nitrate and ammonium aerosols and their radiative effects, Atmos. Chem Phys., 12, 9479-9504, https://doi.org/10.5194/acp-12-94792012, 2012.

Yarwood, G., Jung, J., Whitten, G. Z., Heo, G., Mellberg, J., and Estes, M.: Updates to the Carbon Bond mechanism for version 6 (CB6), in: 2010 CMAS Conference, October 2010, Chapel Hill, NC, http://www.cmascenter.org/conference/2010/abstracts/ emery_updates_carbon_2010.pdf (last access: 18 August 2017), 2010.

Ye, X., Ma, Z., Zhang, J., Du, H., Chen, J., Chen, H., Yang, X., Gao, W., and Geng, F.: Important role of ammonia on haze formation in Shanghai, Environ. Res. Lett, 6, 024019, https://doi.org/10.1088/1748-9326/6/2/024019, 2011. 